\title{
How hidden is the diversity of the genus Cosmarium (Desmidiaceae) in the Brazilian Caatinga?
}

\section{Geraldo José Peixoto Ramos ${ }^{1 *}$ (D), Maria Aparecida dos Santos ${ }^{1}$ (D) and Carlos Wallace do Nascimento Moura ${ }^{1}$ (D)}

Received: August 4, 2020

Accepted: October 12, 2020

\begin{abstract}
The Caatinga domain is the largest and most diverse tropical semiarid ecoregion of South America; however, little is known about the diversity of desmids it harbors, especially the genus Cosmarium (Desmidiaceae, Zygnematophyceae). Our study contributes to the knowledge of Cosmarium in the Caatinga through the report of 42 interesting taxa, including a new species (Cosmarium imperiale), 22 new records for South America, and 19 additions to the desmid flora from Brazil. The samples were gathered from periphytic material from the "Pantanal dos Marimbus" in the Chapada Diamantina region of Northeast Brazil. We provide taxonomic notes, ecological information, including habitat conditions with limnological data, and updated global distributions for all taxa of Cosmarium. A complementary quantitative study was performed during the last year of sampling (2018), which revealed that most taxa have their highest densities in the months with low precipitation and when the water's conductivity and transparency are greater. Our results also have implications for the conservation of the biota from Marimbus do Baiano and understand South America's desmids' biogeography since some rare taxa identified here were previously only known from other continents such as Europe and Africa.
\end{abstract}

Keywords: algae, desmids, periphyton, scanning electron microscopy, semiarid region, taxonomy

\section{Introduction}

South America is characterized by having a mosaic of phytogeographical domains, with diverse types of environments from dry deserts to very wet rainforests and semiarid areas (Moro et al. 2016). Among the most interesting semiarid regions from that continent, one of the most interesting is the Caatinga domain, which is considered the largest and most diverse tropical semiarid ecoregion from South America. This is the only biome found exclusively in Brazil (Leal et al. 2003; Silva \& Souza 2018). Despite that, little is known on the diversity of freshwater algae in that domain, especially desmids, since just a few taxonomic studies have been performed there.

Desmids comprise a polyphyletic algal group, with great phenotypical plasticity, occurring in various types of freshwater habitats, although they are generally more common and diverse in oligotrophic environments (Brook 1981; 1984; Gerrath 1993; Coesel \& Meesters 2007; Gontcharov \& Melkonian 2011). In Brazil, desmids have been reported in taxonomic studies since the 19th century (Ehrenberg 1843; Nordstedt 1870; Borge 1899). Overall, the taxonomic studies on desmids of Brazil can be classified into two phases: (1) until the mid of 20th century, where the foreign researchers were the main contributors, especially

1 Programa de Pós-Graduação em Botânica, Universidade Estadual de Feira de Santana, 44036-900, Feira de Santana, BA, Brazil

* Corresponding author: geraldojpr@gmail.com 
Borge (1903; 1918; 1925), Grönblad (1945), Krieger (1950), Prescott (1957), Förster (1963; 1964), Scott et al. (1965), (2) from the 1960s until nowadays, the Brazilian researchers were the main contributors, usually studying desmids from the southeastern and southern regions.

Until the late 2000s, Northeastern Brazil was one of the regions with the least known desmid flora. However, in the last decade, the studies in that region have been considerably expanded, particularly in the eastern part of the Bahia State, with records of several new and rare species of desmids, including interesting taxa of the genus Cosmarium Corda ex Ralfs (Oliveira et al. 2010; 2011; Ramos et al. 2018; 2019; 2020).

Cosmarium is one of the oldest genera of Desmidiaceae, in addition to having the largest number of taxa described (over 1500 species and several intraspecific taxa) (Guiry \& Guiry 2020). The genus is characterized by having solitary cells, with shallow to deep median constriction, semicells morphologically diverse, rounded, elliptical, oblong, pyramidate, quadrate to rectangular, margins rounded or undulated, cell wall smooth or ornamented by scattered pores, granules, verrucae, chloroplast axial, with one or two pyrenoids per semicell, and some species might have a mucilage sheath surrounding the cells (Bicudo \& Menezes 2017; Guiry \& Guiry 2020). In Brazil, there are about 650 taxa (including taxa not nominated), of which over 200 were described based on Brazilian material (Biolo \& Bicudo 2018). In contrast, there are about 120 taxa reported in the Bahia State, generally from the eastern part (coastal plains of the northern region) and only 12 to the Chapada Diamantina region.

Overall, taxonomic studies on desmids from the Caatinga are rather scarce. Little is known on the current known diversity and distribution of that algal group in that northeastern Brazil's semiarid biome. Based only on taxonomic and floristic studies (Förster 1964; Ramos et al. 2019; 2020), there are only 13 taxa of Cosmarium reported to that domain (12 from Bahia and only one in Piaui), including some endemic taxa such as Cosmarium decedens var. bahiense, C. diamantinum, C. femmeasense, and C. subundulatum var. ellipticum. To increase the knowledge on the biodiversity and distribution of desmids from the Caatinga, the present paper reports 42 interesting taxa of Cosmarium, including a new species and rare taxa reported or confirmed for the first time to the desmid flora of Brazil or South America.

\section{Material and methods}

One hundred periphytic samples were collected during the years 2011, 2012, 2017, and 2018 in the "Pantanal dos Marimbus", a floodplain located between the Andaraí and Lençóis municipalities, Chapada Diamantina region, Bahia State, northeastern Brazil (Fig. 1). Those wetlands have been considered important ecosystems in the Chapada
Diamantina, Caatinga domain, harboring rich biodiversity and hence were partially incorporated into the MarimbusIraquara Environmentally Protected Area by Gubernatorial Decree in the 1990s. The samples were gathered through the squeezing of three species of aquatic macrophytes: Utricularia foliosa L., Cabomba caroliniana A. Gray, and Nymphaea amazonum Mart \& Zucc. These plants have distinct morphologies and form large populations in the study area.

We measured limnological parameters in the natural habitats during the years of 2017 and 2018, such as the temperature ( $\mathrm{T}), \mathrm{pH}$, electric conductivity $(\mathrm{EC})$ and total dissolved solids (TDS) using a multiparameter portable probe (Hanna HI98130), dissolved oxygen (DO) using an Instrutherm device (MO-910), depth and water transparency (WT) using a Secchi disk. The precipitation values were consulted in the database of the Instituto Nacional de Meteorologia (INMET 2020). Although periods of rain and drought are generally well defined in the Pantanal dos Marimbus region, precipitation data in 2018 were considered atypical, with rains concentrated in June (historically dry month) and drought in April (generally a rainy month). Thus, here we consider for the year 2018 the dry period the following months, April, June, and October, whereas for the rainy period the months of February, June, and December. For most taxa, we provided the values of limnological parameters represented by the mean and standard deviation.

The samples collected in 2011, 2012, and 2017 were used only for qualitative analysis. On the other hand, the material from 2018 was periodically collected (bimestrial, February to December) by the scraped area in each studied macrophyte and used for both qualitative and quantitative analysis. Thus, only the data from 2018 were submitted to statistical analysis.

The Redundancy Analysis (RDA) was performed to verify the relationship between the limnological parameters and the Cosmarium taxa in "Marimbus do Baiano" during 2018. The multicollinearity of the environmental variables was evaluated based on the variance inflation factor (VIF). Considering the AIC criterium, we used the forwardselection method to reduce the data's dimensionality (Blanchet et al. 2008; Oksanen et al. 2011). The matrix with the taxa's density values was standardized according to the transformation of "Hellinger" (Legendre \& Gallagher 2001). We performed a permutation test (999 permutations) to evaluate the model's significance and the RDA axes. The analysis was performed using R software (R Development Core Team 2020).

All the materials were examined under an Olympus BX45 Optical Microscope and photographed using a MicroPublisher - QImaging MP5.0-RTV-CLR-10-C digital camera. Some samples were dried, coated with gold based on protocols of Ramos et al. (2017), and observed through scanning electron microscopy (SEM). The samples were 

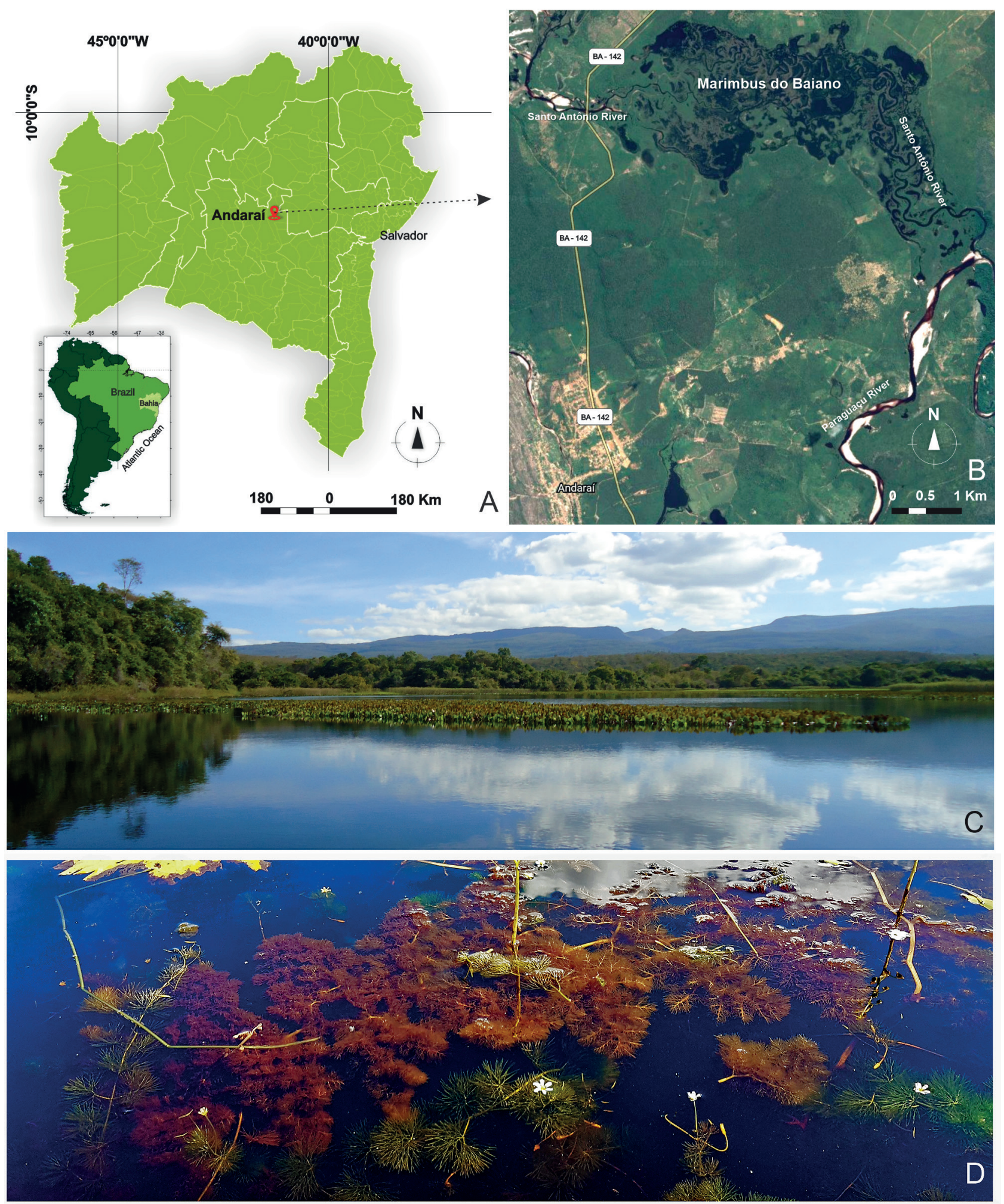

Figure 1. Study area. A. Location of Andaraí municipality in the Bahia State, Brazil; B. Satellite image showing the Santo Antonio River and Pantanal dos Marimbus (Baiano), Chapada Diamantina (Google Earth); C. General view of Pantanal dos Marimbus (Baiano). D. Some aquatic macrophytes of the Pantanal dos Marimbus: Utricularia foliosa (brownish specimens) and Cabomba caroliniana (greenish specimens). 
preserved in Transeau's solution (Bicudo \& Menezes 2017) and subsequently incorporated into the liquid collection in the herbarium of the Universidade Estadual de Feira de Santana (HUEFS). The samples for counting were fixed in Lugol solution $(0.5 \%)$, and the quantification was performed in an Inverted Microscope (Olympus IX51). We used the random field method (Uehlinger 1964), establishing as a counting limit the observation of 10 random fields without the occurrence of new taxa.

The identification of the taxa was based on morphological features. It was performed using specialized literature, such as West \& West (1896; 1898; 1908), Krieger \& Gerloff (1962; 1965; 1969), Scott \& Grönblad (1957), Prescott et al. (1981), Thérézien (1985), Coesel \& Meesters (2007), among others.

Additional approaches, including taxonomic notes for each taxon, habitat conditions, updated worldwide distribution, and richness of Cosmarium in the macrophytes, are provided. Moreover, a quantitative study was conducted based on samples collected in 2018 to evaluate the relation between the limnological parameters and the Cosmarium taxa density.

\section{Results and discussion}

Our research revealed 42 interesting taxa of Cosmarium occurring in a floodplain from the Caatinga domain, including a new species and 41 additions to Brazil or South America's desmid flora.

\section{Taxonomic treatment}

1. Cosmarium amoenum var. compactum West \& G.S.West, Trans. Linn. Soc. Lond., ser. 2, Botany 5: 251. 1896.

(Fig. 2A-D).

Cell dimensions - length $32.5-42.5 \mu \mathrm{m}$, breadth $27-$ $31.5 \mu \mathrm{m}$, breadth of isthmus $11.5-13 \mu \mathrm{m}$.

Habitat - This variety was generally associated with periphyton of Nymphaea amazonum and Utricularia foliosa. Conductivity $0.04\left( \pm 0.03 \mathrm{mS} . \mathrm{cm}^{-1}\right)$; dissolved oxygen 6.8 ( \pm 1.4 mg. $\left.\mathrm{L}^{-1}\right) ; \mathrm{pH} 6.8( \pm 0.4) ;$ total dissolved solids 0.02 ( \pm 0.018$)$; water temperature $30.3\left( \pm 1.8^{\circ} \mathrm{C}\right)$; water transparency $0.64( \pm 0.19 \mathrm{~m})$.

Distribution - North America (Canada); South America: Brazil (first record).

Material examined - BRAZIL. Bahia: Andaraí, Pantanal dos Marimbus (Baiano), 18/II/2018, M.A.Santos et al. s/n (HUEFS 253740, HUEFS 253743, HUEFS 253749).

Note - Cosmarium amoenum var. compactum differs from the nominate variety by having semicircular cells with vertical series of granules. This variety is rarely reported in the literature and is probably endemic to the American continent. Morphologically, it resembles Cosmarium conspersum var. attenuatum Nordst., but this latter variety differs by having larger cells (66-77 $\mu \mathrm{m} \times 51-58 \mu \mathrm{m})$, with more granules, which are arranged in concentric ellipses in the apical view.

2. Cosmarium anceps P.Lundell, Nova Acta R. Soc. Sc. Upsal., ser. 3, 8 (2): 48. 1871.

(Fig. 2E-F).

Cell dimensions - length $21 \mu \mathrm{m}$, breadth $14.5 \mu \mathrm{m}$, breadth of isthmus $7.5 \mu \mathrm{m}$.

Habitat - This species was found associated with periphyton of Utricularia foliosa. Conductivity $0.06 \mathrm{mS} . \mathrm{cm}^{-1}$; dissolved oxygen $5.9 \mathrm{mg} \cdot \mathrm{L}^{-1} ; \mathrm{pH}$ 6.9; total dissolved solids 0.03; water temperature $29.9^{\circ} \mathrm{C}$; water transparency $0.76 \mathrm{~m}$.

Distribution - Cosmopolitan; South America: Brazil (first record).

Material examined - BRAZIL. Bahia: Andaraí, Pantanal dos Marimbus (Baiano), 18/II/2018, M.A.Santos et al. s/n (HUEFS 253742).

Note - Cosmarium anceps is characterized by having trapezoid semicells with concave sides, broadly elliptic in apical view. This species has a wide distribution; however, there are no taxonomic records in Brazil. Even in other regions from South America, the records are unclear. According to West \& West (1908), C. anceps is a very characteristic alpine and subalpine species, occurring among mosses on the dripping rocks of mountain glens and boggy springs high up on the mountains. In the Marimbus, a few specimens were observed associated with Utricularia foliosa.

3. Cosmarium anisochondrum var. isthmolatum Thérézien, Biblioth. Phycol.72: 93. 1985.

(Fig. 2G-J).

Cell dimensions - length $23.5-24 \mu \mathrm{m}$, breadth $13 \mu \mathrm{m}$, breadth of isthmus $3.5 \mu \mathrm{m}$.

Habitat - This variety was found generally associated with periphyton of Utricularia foliosa, Nymphaea amazonum and Cabomba caroliniana. Conductivity $0.06\left( \pm 0.02 \mathrm{mS} . \mathrm{cm}^{-1}\right)$; dissolved oxygen $6.8\left( \pm 1.6 \mathrm{mg} \cdot \mathrm{L}^{-1}\right)$; pH $6.8( \pm 0.4)$; total dissolved solids 0.03 ( \pm 0.015); water temperature 28.7 $\left( \pm 2.2^{\circ} \mathrm{C}\right)$; water transparency $0.8( \pm 0.15 \mathrm{~m})$.

Distribution - South America: French Guiana, Brazil (first record).

Material examined - BRAZIL. Bahia: Andaraí, Pantanal dos Marimbus (Baiano), 18/II/2018, M.A.Santos et al. s/n (HUEFS 253741, HUEFS 253750); 09/IV/2018, M.A.Santos et al. s/n (HUEFS 253753).

Note - The var. isthmolatum differs from the nominate variety by having two larger subapical granules. In the median region of the semicell, there are double granules surrounded by two vertical rows of 2-3 granules and a horizontal row composed of 3 supraisthmal granules. This variety is very rare, known only so far in French Guiana (type locality, Thérézien 1985). Coesel (1992), based on samples from Colombia, identified $C$. dichondrum, but after analyzing the figures 
provided by the author (Coesel 1992: Pl. 3, Figs. 9,10), and mainly the cell wall pattern, we consider the taxon closer to C. anisochondrum var. isthmolatum than C. dichondrum. Thus, it is possible this variety also might occur in Colombia. The few records, all of them from South America, suggest the endemism of this variety for that region.

4. Cosmarium baccatum Scott \& Grönblad, Acta Soc. Sci. Fenn. Nov. Ser. B. 2(8): 15. 1957.

(Fig. 2K-O),
Cell dimensions - length 70-72.5 $\mu \mathrm{m}$, breadth 59$61.5 \mu \mathrm{m}$, breadth of isthmus $15-17 \mu \mathrm{m}$.

Habitat - This species was found generally associated with periphyton of Cabomba caroliniana. Conductivity $0.02 \mathrm{mS} . \mathrm{cm}^{-1}$; dissolved oxygen $12 \mathrm{mg} . \mathrm{L}^{-1}$; $\mathrm{pH}$ 7.5; total dissolved solids 0.01; water temperature $22^{\circ} \mathrm{C}$; water transparency $2.1 \mathrm{~m}$.

Distribution - North America (USA); Asia (Korea); South America, Brazil (first record).

Material examined - BRAZIL. Bahia: Lençóis, Pantanal dos Marimbus (Remanso), 20/VIII/2011, G.J.P.Ramos

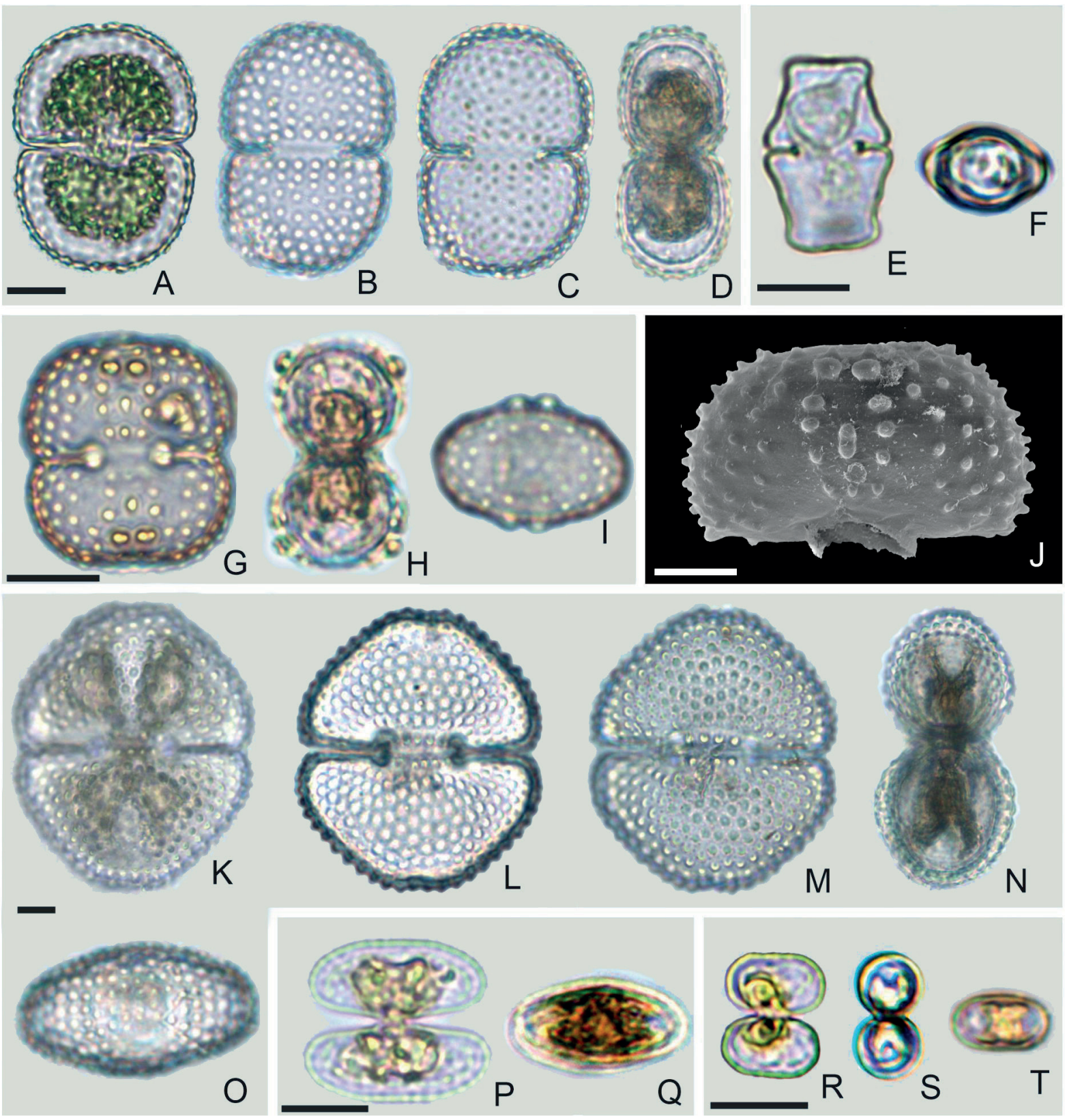

Figure 2. Cosmarium from the Pantanal dos Marimbus. A-D. Cosmarium amoenum var. compactum: frontal view (A-C), lateral view (D); E-F. Cosmarium anceps: frontal view (E), apical view (F); G-J. Cosmarium anisochondrum var. isthmolatum: frontal view (G), lateral view (H), apical view (I), detail of ornamentation of the semicell in SEM (J); K-O. Cosmarium baccatum: frontal view (K-M), lateral view $(\mathbf{N})$, apical view (O); P-Q. Cosmarium bioculatum var. boreale: frontal view (P), apical view (Q); R-T. Cosmarium bioculatum var. hians: frontal view $(\mathbf{R})$, lateral view $(\mathbf{S})$, apical view $(\mathbf{T})$. Scale bar $10 \mu \mathrm{m}(\mathrm{LM}), 5 \mu \mathrm{m}(\mathrm{SEM})$. 
\& C.W.N. Moura s/n (HUEFS 185359); 11/II/2012, G.J.P.Ramos \& C.A.Ribeiro s/n (HUEFS 185418).

Note - Cosmarium baccatum is a rare species described by Scott \& Grönblad (1957) based on material from Florida, USA. This species is primarily characterized by having subpyramidate semicells, rotundate basal angles, truncate apices, and ornamented with granules surrounded by pores. A row with 3-4 granules is also noteworthy in the isthmus region.

The occurrence out of North America has been somewhat uncertain: Jung et al. (2017) reported its occurrence to Korea; however, the specimens illustrated (Fig. 2A-D) resemble more Cosmarium decoratum West \& G.S.West than C. baccatum. On the other hand, the morphological features of Brazilian specimens agree with those described by Scott \& Grönblad (1957); therefore, the geographic distribution of species has been expanded to South America.

5. Cosmarium bioculatum var. boreale (Børgesen) Willi Krieger \& Gerloff, Die Gattung Cosmarium, Lieferung 1: 62. 1962.

$\equiv$ Cosmarium boreale Børgesen, Vid. Medd. Naturh. For. Kjøbenhavn 51: 328 (1899).

(Fig. 2P-Q).

Cell dimensions - length $18-19 \mu \mathrm{m}$, breadth $21-22.5$ $\mu \mathrm{m}$, breadth of isthmus $4-5.5 \mu \mathrm{m}$.

Habitat - This variety was found generally associated with periphyton of Utricularia foliosa and Cabomba caroliniana. Conductivity $0.06\left( \pm 0.01 \mathrm{mS} . \mathrm{cm}^{-1}\right)$; dissolved oxygen 7.1 ( $\left.\pm 1.7 \mathrm{mg} . \mathrm{L}^{-1}\right)$; $\mathrm{pH} 7( \pm 0.5)$; total dissolved solids $0.03( \pm 0.01)$; water temperature $32\left( \pm 2.6^{\circ} \mathrm{C}\right)$; water transparency 0.77 ( $\pm 0.13 \mathrm{~m})$.

Distribution - Europe; South America: Brazil (first record).

Material examined - BRAZIL. Bahia: Andaraí, Pantanal dos Marimbus (Baiano), 23/V/2017, G.J.P.Ramos et al. s/n (HUEFS 242423, HUEFS 242434); 18/IX/2017, M.A.Santos et al. s/n (HUEFS 242484).

Note - Cosmarium bioculatum var. boreale differs from the nominate variety by having numerous pores on the cell wall, which resemble small granules due to mucilage remains. This variety can be confused with $C$. perfissum G.S.West, which differs in having oblong-elliptical semicells, usually with slightly convex apices. However, during the description of C. perfissum, West (1909) provided a morphological variation (Fig.2A) with rounded apices, identical to C. bioculatum var. boreale. When the cells of $C$. perfissum are observed in apical view, it is possible to see mild median inflation, which is absent in the var. boreale. Thus, we consider the apical view another important feature to separate both taxa.

6. Cosmarium bioculatum var. hians West \& G.S.West, J. Roy. Micr. Soc. 17(6): 486. 1897.

(Fig. 2R-T).
Cell dimensions - length 12.5-14 $\mu \mathrm{m}$, breadth 9$10.5 \mu \mathrm{m}$, breadth of isthmus 3-4.5 $\mu \mathrm{m}$.

Habitat - This variety was found generally associated with periphyton of Utricularia foliosa and Cabomba caroliniana. Conductivity $0.07\left( \pm 0.025 \mathrm{mS} . \mathrm{cm}^{-1}\right)$; dissolved oxygen 6.5 ( $\left.\pm 1.8 \mathrm{mg} . \mathrm{L}^{-1}\right)$; $\mathrm{pH} 7.6( \pm 0.6)$; total dissolved solids $0.03( \pm 0.01)$; water temperature $28.7\left( \pm 1.2^{\circ} \mathrm{C}\right)$; water transparency $0.80( \pm 0.22 \mathrm{~m})$.

Distribution - Cosmopolitan; South America: Brazil (first record).

Material examined - BRAZIL. Bahia: Andaraí, Pantanal dos Marimbus (Baiano), 12/VI/2018, M.A.Santos et al. s/n (HUEFS 253765, HUEFS 253769); 22/VIII/2018, M.A.Santos et al. s/n (HUEFS 253777, HUEFS 253778, HUEFS 253780, HUEFS 253783).

Note - This variety is widely known in diverse regions globally; however, its occurrence is unknown in Brazil and other areas from South America. Recently, Rosen et al. (2019) reported the var. hians at the Arthur R. Marshall Loxahatchee National Wildlife Refuge, another Tropical wetland located in the Everglades, Florida.

In the Marimbus, this variety was very rare; just a few specimens were observed. Krieger \& Gerloff (1969) synonymized Cosmarium bioculatum var. hians to C. asphaerosporum var. strigosum Nordst. Although these taxa to be morphologically identical, we still consider them distinct (Cosmarium bioculatum var. hians differs by having cells more robust and punctuated cell wall), therefore agreeing with recent studies such as Petlovany \& Tsarenko (2015) and Kanetsuna \& Yamagishi (2018). However, further studies with other approaches such as SEM and molecular data are recommended to verify the relation of those taxa.

7. Cosmarium bireme var. barbadense G.S.West, J. Bot 42: 286. 1904.

(Fig. 3A-D).

Cell dimensions - length $15 \mu \mathrm{m}$, breadth $13 \mu \mathrm{m}$, breadth of isthmus $4 \mu \mathrm{m}$.

Habitat - This variety was found generally associated with periphyton of Utricularia foliosa and Cabomba caroliniana. Conductivity $0.03\left( \pm 0.017 \mathrm{mS} . \mathrm{cm}^{-1}\right)$; dissolved oxygen $6.5\left( \pm 1.5 \mathrm{mg} \cdot \mathrm{L}^{-1}\right) ; \mathrm{pH} 6.7( \pm 0.9)$; total dissolved solids $0.005( \pm 0.01)$; water temperature $30.8\left( \pm 0.8^{\circ} \mathrm{C}\right)$; water transparency $0.60( \pm 0.15 \mathrm{~m})$.

Distribution - North America (USA), Europe (Italy), Africa (Burundi), Asia (Bangladesh); South America: Brazil (Mato Grosso - ?; Bahia - first confirmed record).

Material examined - BRAZIL. Bahia: Andaraí, Pantanal dos Marimbus (Baiano), 09/XII/2011, G.J.P.Ramos \& C.A.Ribeiro. s/n (HUEFS 185390); 18/II/2018, M.A.Santos et al. s/n. (HUEFS 253745, HUEFS 253750); 12/VI/2018, M.A.Santos et al. s/n. (HUEFS 253766); 04/XII/2018, M.A.Santos et al. s/n. (HUEFS 253804). 


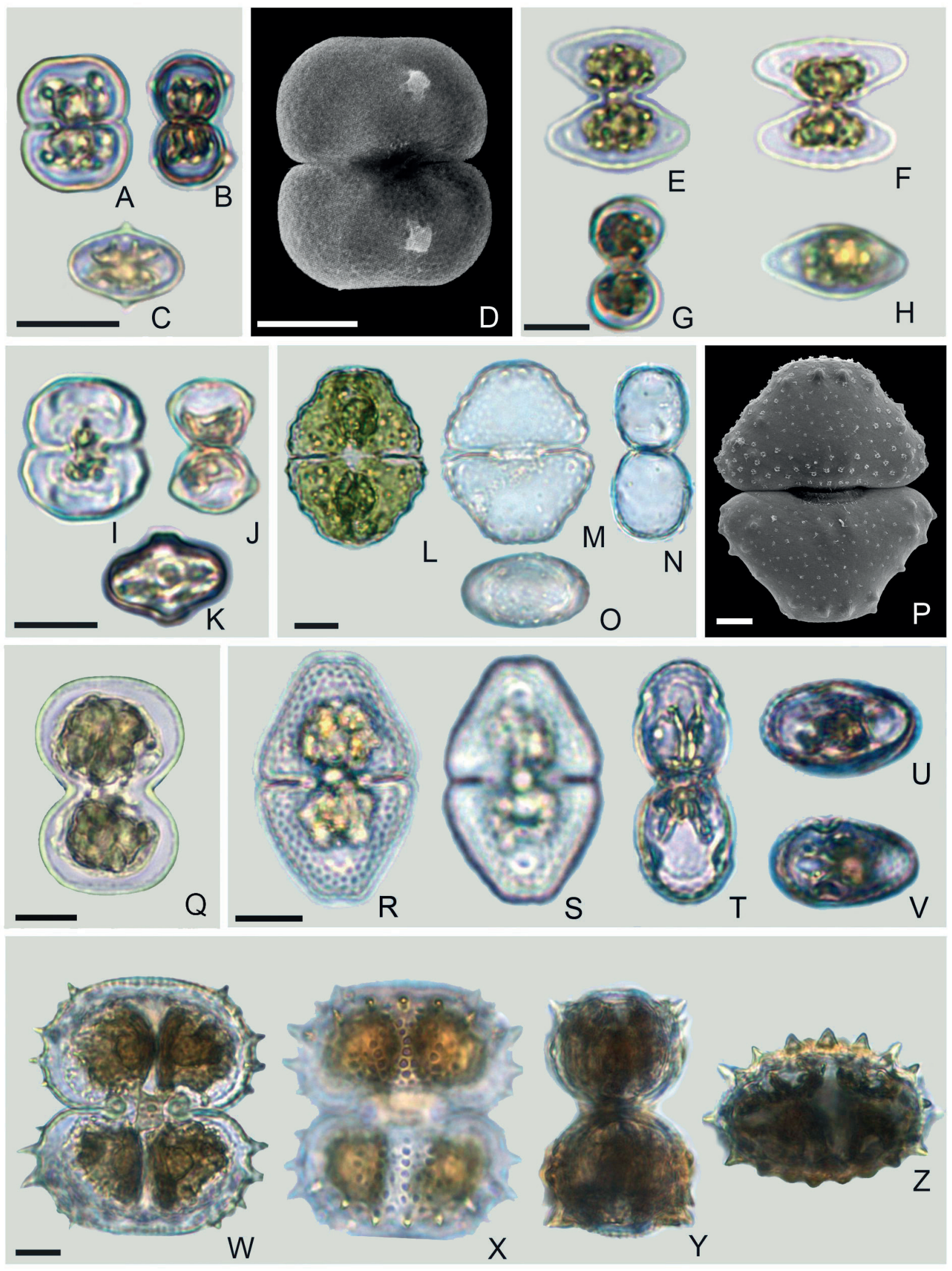

Figure 3. Cosmarium from the Pantanal dos Marimbus A-D. Cosmarium bireme var. barbadense: frontal view (A, D), lateral view (B), apical view (C), Detail of the cell wall in SEM (D); E-H. Cosmarium capitulum: frontal view (E, H), lateral view (G), apical view (H); I-K. Cosmarium clepsydra var. alaskanum: frontal view (I), lateral view (J), apical view (K); L-P. Cosmarium columbianum: frontal view $(\mathbf{L}, \mathbf{M}, \mathbf{P})$, lateral view $(\mathbf{N})$, apical view $(\mathbf{O})$, Detail of the cell wall in SEM (P); $\mathbf{Q}$. Cosmarium connatum var. truncatum: frontal view (Q); R-V. Cosmarium granatum var. ocellatum: frontal view $(\mathbf{R}-\mathbf{S})$, lateral view $(\mathbf{T})$, apical view (U-V); W-Z. Cosmarium guatemalense: frontal view (W-X), lateral view (Y), apical view (Z). Scale bar $10 \mu \mathrm{m}(\mathrm{LM}), 5 \mu \mathrm{m}$ (SEM). 
Note - This variety was previously reported in Brazil by De-Lamonica-Freire \& Heckman (1996) for the State of Mato Grosso do Sul. Still, the taxon was just mentioned in a checklist, without any additional taxonomic information (i.e., cell dimensions and illustrations), therefore making it impossible to confirm its identification. Thus, the present record confirms the occurrence of this variety in Brazil.

8. Cosmarium capitulum Roy \& Bisset, J. Bot. 24: 195. 1886.

(Fig. 3E-H).

Cell dimensions - length $16 \mu \mathrm{m}$, breadth $19 \mu \mathrm{m}$, breadth of isthmus $5 \mu \mathrm{m}$.

Habitat - This species was found associated with periphyton of Utricularia foliosa. Conductivity $0.05 \mathrm{mS} . \mathrm{cm}^{-1}$; dissolved oxygen $6.8 \mathrm{mg} \cdot \mathrm{L}^{-1}$; $\mathrm{pH}$ 7; total dissolved solids 0.02 ; water temperature $27.8^{\circ} \mathrm{C}$; water transparency $0.6 \mathrm{~m}$.

Distribution - Cosmopolitan; South America: Chile, Brazil (Espírito Santo - ?; Bahia - first confirmed record).

Material examined - BRAZIL. Bahia: Andaraí, Pantanal dos Marimbus (Baiano), 23/V/2017, G.J.P.Ramos et al. s/n (HUEFS 241798, HUEFS 242434).

Note - The occurrence of $C$. capitulum in Brazil has been somewhat uncertain, as the only taxonomic record was performed by Delazari-Barroso et al. (2007) as "Cosmarium cf. capitulum" based on phytoplankton samples from Duas Bocas Reservoir, Espírito Santo State. Analyzing Fig. 53 provided by the referred authors, we noted that the taxon illustrated probably does not correspond to $C$. capitulum, especially the apical view that is more oval than elliptic, differing from the material described and illustrated by Roy \& Bisset (1886: 195, Fig. 9). Another taxon that is very similar to $C$. capitulum is Staurastrum pachyrhynchum var. tenerum Grönblad, which differs primarily in having triangular cells in apical view.

9. Cosmarium clepsydra var. alaskanum Croasdale, Trans. Amer. Micros. Soc. 75(1): 22. 1956.

(Fig. 3I-K).

Cell dimensions - length $17 \mu \mathrm{m}$, breadth $15 \mu \mathrm{m}$, breadth of isthmus $5 \mu \mathrm{m}$.

Habitat - This species was found associated with periphyton of Utricularia foliosa. Conductivity $0.01 \mathrm{mS} . \mathrm{cm}^{-1}$; dissolved oxygen $6.8 \mathrm{mg} \cdot \mathrm{L}^{-1} ; \mathrm{pH}$ 8.1; total dissolved solids 0.01 ; water temperature $26.7^{\circ} \mathrm{C}$; water transparency $0.85 \mathrm{~m}$.

Distribution - North America (USA: Alaska), Europe (Norway); South America: Brazil (first record).

Material examined - BRAZIL. Bahia: Andaraí, Pantanal dos Marimbus (Baiano), 23/V/2017, G.J.P.Ramos et al. s/n (HUEFS 242426); 18/IX/2017, M.A.Santos et al. s/n. (HUEFS 242479); 23/X/2018, M.A.Santos et al. s/n. (HUEFS 253790).

Note - This variety differs from the nominate variety in the semicells being in general octagonal-elliptic rather than triangular in face view. Croasdale (1956), during the diagnosis of the var. alaskanum also mentioned that the median protuberance is 3-dentate, although it is not always easily distinguished. The specimens which we examined had variable protuberance from non-dentade to 3-dentade (rare), therefore we consider the octagonal-elliptic shape of semicells to be the best feature to distinguish from the nominate variety.

It was surprising to find this variety in northeastern Brazil. Its occurrence has been so far known only to the Temperate region (subarctic), where the temperatures are generally relatively low. Despite that, $\mathrm{pH}$ conditions from the Marimbus ( $\mathrm{pH}=6.8-8.1$ ) agree with those reported by Croasdale for Alaska samples (6.4-8.6, with $\mathrm{pH} 8.0$ the most typical condition).

10. Cosmarium columbianum G.S.West, Mem. Soc. Sci. nat. Neuchatel 5(2): 1036. 1914.

(Fig. 3L-P).

Cell dimensions - length 41.5-42.5 $\mu \mathrm{m}$, breadth 33.5$36 \mu \mathrm{m}$, breadth of isthmus 10.5-12.5 $\mu \mathrm{m}$.

Habitat - This variety was found generally associated with periphyton of Utricularia foliosa and Nymphaea amazonum. Conductivity $0.06\left( \pm 0.023 \mathrm{mS} . \mathrm{cm}^{-1}\right)$; dissolved oxygen 6.3 ( $\left.\pm 1.2 \mathrm{mg} . \mathrm{L}^{-1}\right)$; pH 6.9 ( \pm 0.6$)$; total dissolved solids 0.03 ( \pm 0.01$)$; water temperature $30.5\left( \pm 1.1{ }^{\circ} \mathrm{C}\right.$ ); water transparency $0.74( \pm 0.07 \mathrm{~m})$.

Distribution - South America: Colombia, Brazil (first record).

Material examined - BRAZIL. Bahia: Andaraí, Pantanal dos Marimbus (Baiano), 23/V/2017, G.J.P.Ramos et al. s/n (HUEFS 242420, HUEFS 242434); 18/IX/2017, M.A.Santos et al. s/n. (HUEFS 242479); 09/XII/2011, G.J.P.Ramos \& C.A.Ribeiro s/n. (HUEFS 185390).

Note - This is a rare species, known so far only in high altitude mountains from Colombia. It is quite similar to Cosmarium corumbense Borge. However, this latter species differs by having a cell with few granules at lower lateral sides, and in apical view, the granules are arranged at margins, not in ring-like as $C$. columbianum. The SEM analysis revealed the punctuations seen under LM, actually, are pores with mucilage remains revesting all the cell.

11. Cosmarium connatum var. truncatum West, Bot. J. Linn. Soc. 29: 161. 1892.

(Fig. 3Q).

Cell dimensions - length $45 \mu \mathrm{m}$, breadth $25 \mu \mathrm{m}$, breadth of isthmus $20 \mu \mathrm{m}$.

Habitat - This variety was found associated with periphyton of Nymphaea amazonum. Conductivity 0.06 $\mathrm{mS} . \mathrm{cm}^{-1}$; dissolved oxygen $5.9 \mathrm{mg} . \mathrm{L}^{-1} ; \mathrm{pH}$ 6.9; total dissolved solids 0.03 ; water temperature $29.9^{\circ} \mathrm{C}$; water transparency $0.76 \mathrm{~m}$. 
Distribution - Europe, Asia; South America: Brazil (first record).

Material examined - BRAZIL. Bahia: Andaraí, Pantanal dos Marimbus (Baiano), 18/II/2018, M.A.Santos et al. s/n. (HUEFS 253740).

Note - The var. truncatum was described by West (1892) based on material from Ireland. It differs from the nominate variety by having truncate apices and deeper median constriction. This variety is rare in the study area, occurring associated with Nymphaea amazonum.

12. Cosmarium granatum var. ocellatum West \& G.S.West, Trans. Amer. Micros. Soc. 5: 246. 1896.

(Fig. 3R-V).

Cell dimensions - length $33.5-40 \mu \mathrm{m}$, breadth $20.5 \mu \mathrm{m}$, breadth of isthmus $8 \mu \mathrm{m}$.

Habitat - This variety was found associated with periphyton of Utricularia foliosa. Conductivity $0.01 \mathrm{mS} . \mathrm{cm}^{-1}$; $\mathrm{pH}$ 6.9; total dissolved solids 0.01 ; water temperature $28.1^{\circ} \mathrm{C}$; water transparency $0.7 \mathrm{~m}$.

Distribution - North America (Canada, USA), Europe (Italy), Asia (India, Sri Lanka, Japan); South America: Brazil (Paraná - ?, Bahia - first confirmed record).

Material examined - BRAZIL. Bahia: Andaraí, Pantanal dos Marimbus (Baiano), 29/VI/ 2011, G.J.P.Ramos \& C.A.Ribeiro s/n. (HUEFS 178376); Lençóis, Pantanal dos Marimbus (Remanso), 11/II/2012, G.J.P.Ramos \& C.A.Ribeiro s/n. (HUEFS 185427).

Note - The only report of this variety in Brazil was performed by Carvalho et al. (2015) based on samples from Campo Mourão, Paraná State. However, the main feature of this variety (cell wall with a large median scrobicle, Fig. 3S) was not mentioned in the description, and it is not clearly visible in the figures provided by authors (Carvalho et al. 2015: Figs. 9, 10). As the presence of scrobicles is doubtful in those specimens from Paraná, we consider the taxon from Bahia the first confirmed record of var. ocellatum in Brazil.

13. Cosmarium guatemalense Taylor, Bot. Not. p.117. 1939.

(Fig. 3W-Z).

Cell dimensions - length 57.5-61.5 $\mu \mathrm{m}$, breadth 47-50 $\mu \mathrm{m}$, breadth of isthmus $12-14.5 \mu \mathrm{m}$.

Habitat - This species was found generally associated with periphyton of Utricularia foliosa. Conductivity 0.06 $\left( \pm 0.008 \mathrm{mS} . \mathrm{cm}^{-1}\right)$; dissolved oxygen $6.6\left( \pm 0.5 \mathrm{mg} . \mathrm{L}^{-1}\right)$; pH 6.9 ( \pm 0.3$)$; total dissolved solids 0.03 ( \pm 0.008$)$; water temperature $27.2\left( \pm 0.4{ }^{\circ} \mathrm{C}\right)$; water transparency 0.60 $( \pm 0.4 \mathrm{~m})$.

Distribution - Central America (Guatemala, Panama); South America: Brazil (first record).

Material examined - BRAZIL. Bahia: Andaraí, Pantanal dos Marimbus (Baiano), 23/V/2017, G.J.P.Ramos et. al. s/n. (HUEFS 241798, HUEFS 242429, HUEFS 242434, HUEFS 242437).

Note - Cosmarium guatemalense is a relatively rare species, described by Taylor (1939) from material collected at Lake Zotz, Guatemala, and known so far only in Central America. This species is identical to Cosmarium paraguayense Borge, but it differs from this latter by having smaller cells with many large shallow pits that may be somewhat scattered or forming U-shaped rows (Fig. 3X).

14. Cosmarium hammeri var. sinuatum Borge, Ark. Bot. 1: 96. 1903.

(Fig. 4A-B).

Cell dimensions - length $25 \mu \mathrm{m}$, breadth $20 \mu \mathrm{m}$, breadth of isthmus $7 \mu \mathrm{m}$.

Habitat - This variety was found associated with periphyton of Cabomba caroliniana. Conductivity 0.01 $\mathrm{mS} . \mathrm{cm}^{-1}$; dissolved oxygen $6.8 \mathrm{mg} . \mathrm{L}^{-1} ; \mathrm{pH}$ 8.1; total dissolved solids 0.01 ; water temperature $26.7^{\circ} \mathrm{C}$; water transparency $0.85 \mathrm{~m}$.

Distribution - South America: Paraguay, Bolivia, Brazil (first confirmed record).

Material examined - BRAZIL. Bahia: Andaraí, Pantanal dos Marimbus (Baiano), 23/X/2018, M.A.Santos et al. s/n. (HUEFS 253789).

Note - This variety was described by Borge (1903) based on samples collected in Areguá, Paraguay. It differs from the nominate variety in having cells with basal lobes slightly concave and a thickened scrobicle, which is better seen at the lateral view. Biolo \& Bicudo (2018) prepared a checklist of Cosmarium from Brazil and reported the occurrence of this variety, but not provided additional information on this record (such as paper where taxon came from, taxonomic data, or even its distribution in Brazil). Thus, the specimens from Bahia represent the first confirmed record for Brazilian flora. This variety is probably endemic to South America.

15. Cosmarium isthmochondrum var. asymmetricum Scott \& Grönblad, Acta. Soc. Sc. Fenn. n.s.B 2(8): 18. 1957.

(Fig. 4C-F).

Cell dimensions - length $14.5-18 \mu \mathrm{m}$, breadth 12.5 $14.5 \mu \mathrm{m}$, breadth of isthmus 3.5-7.5 $\mu \mathrm{m}$.

Habitat - This variety was found generally associated with periphyton of Utricularia foliosa and Cabomba caroliniana. Conductivity $0.03\left( \pm 0.02 \mathrm{mS} . \mathrm{cm}^{-1}\right)$; dissolved oxygen $6.7\left( \pm 0.3 \mathrm{mg} . \mathrm{L}^{-1}\right)$; $\mathrm{pH} 7.7$ ( \pm 0.6$)$; total dissolved solids 0.01 ( \pm 0.01$)$; water temperature $29.2\left( \pm 3.1{ }^{\circ} \mathrm{C}\right)$; water transparency $0.66( \pm 0.26 \mathrm{~m})$.

Distribution - North America, South America: Brazil (Bahia - first confirmed record).

Material examined - BRAZIL. Bahia: Andaraí, Pantanal dos Marimbus (Baiano), 23/V/2017, G.J.P.Ramos et al. s/n. (HUEFS 241798); 18/II/2018, M.A.Santos et al. s/n. 
(HUEFS 253745); 09/IV/2018, M.A.Santos et al. s/n. (HUEFS 253756, HUEFS 253757); 12/VI/2018, M.A.Santos et al. s/n. (HUEFS 253769); 23/X/2018, M.A.Santos \& H.M.D.Oliveira s/n. (HUEFS 253790).

Note - This variety was reported in Brazil by Oliveira et al. (2011) based on samples from the northern coast of Bahia. Despite this, it is not possible to clearly see the details of the wall in the cell face. The semicell outline of Figure 5 (Oliveira et al. 2011) is pyramidate-rectangular, therefore more elongated than the specimens described by Scott \& Grönblad (1957). Perhaps the taxon reported by Oliveira et al. (2011) is Cosmarium inaequalinotatum Scott \& Grönblad (1957), another species that also occurs in the Marimbus. Biolo \& Bicudo (2018) also mentioned the occurrence of var. asymmetricum in a checklist of that genus from Brazil. Still, there is no taxonomic information on that taxon, such as figures or descriptions, making it impossible to re-study.

Nevertheless, independent of the taxon reported by Oliveira et al. (2011) and Biolo \& Bicudo (2018), the present record confirms the occurrence of that variety in Brazil.

Cosmarium isthmochondrum var. asymmetricum is identical to $C$. subdanicum var. bigranulatum Förster, but
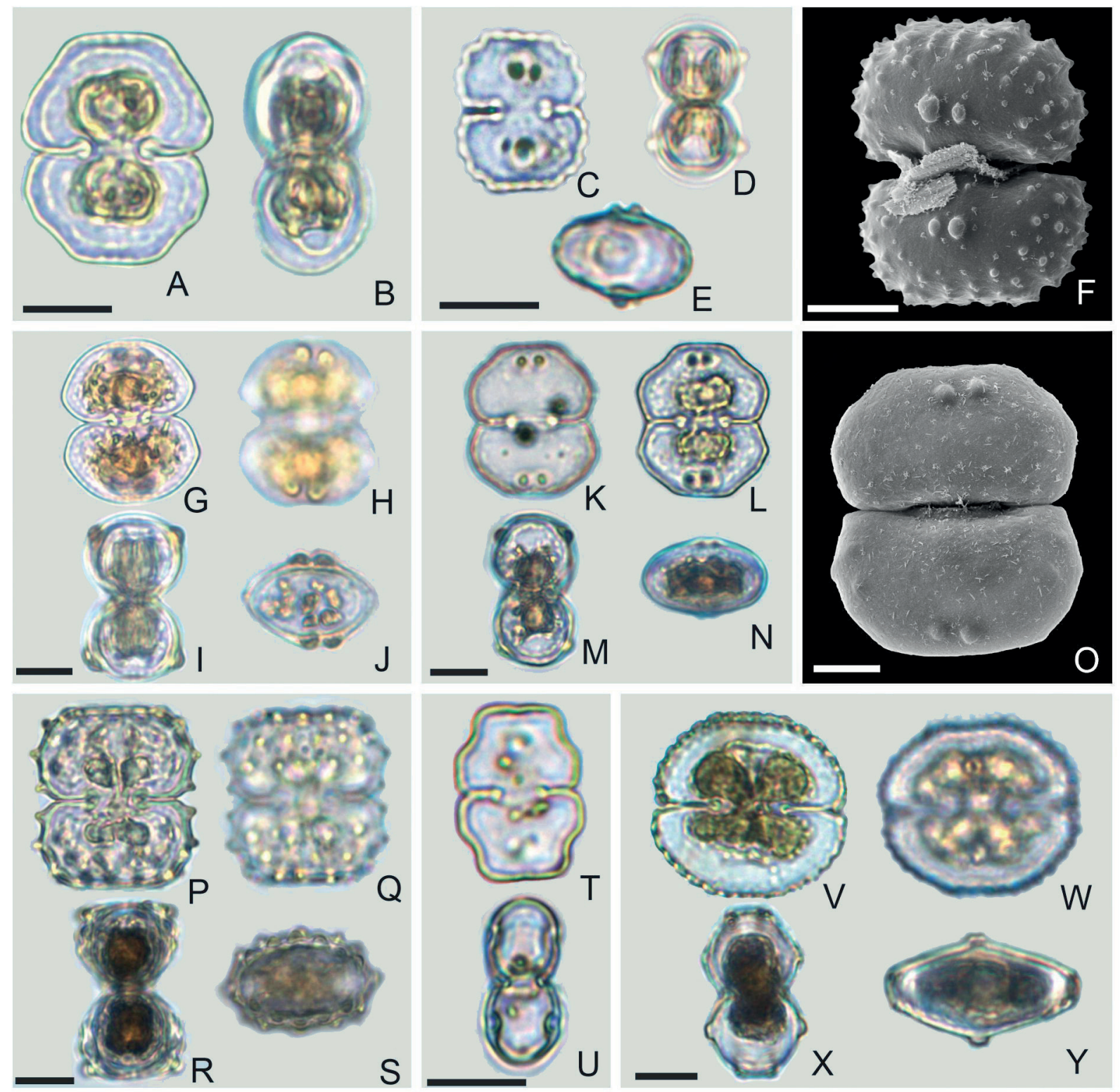

Figure 4. Cosmarium from the Pantanal dos Marimbus A-B. Cosmarium hammeri var. sinuatum: frontal view (A), lateral view (B); C-F. Cosmarium isthmochondrum var. asymmetricum: frontal view $(\mathbf{C})$, lateral view (D), apical view (E), Detail of the cell wall in SEM (F); G-J. Cosmarium mamilliferum var. bituberculatum: frontal view (G-H), lateral view (I), apical view (J); K-O. Cosmarium mamilliferum var. madagascariense: frontal view $(\mathbf{K}-\mathbf{L}, \mathbf{O})$, lateral view $(\mathbf{M})$, apical view $(\mathbf{N})$, Detail of the cell wall in SEM (O); P-S. Cosmarium mayori: frontal view (P-Q); T-U. Cosmarium miedzyrzecense var. monomazum: frontal view (T), lateral view (U); V-Y. Cosmarium monomazum: frontal view $(\mathbf{V}-\mathbf{W})$, lateral view $(\mathbf{X})$, apical view $(\mathbf{Y})$. Scale bar $10 \mu \mathrm{m}(\mathrm{LM}), 5 \mu \mathrm{m}(\mathrm{SEM})$. 
this latter variety differs from having cells with two central granules which are of the same size, and the isthmus region has no granules. However, we recommend further detailed studies to evaluate the relation of those taxa.

16. Cosmarium mamilliferum var. bituberculatum (F.E.Fritsch \& M.F.Rich) Bourrelly, Bull. Inst. Franç. Afr. Noire, ser. A, 19: 1070. 1957.

$\equiv$ Cosmarium bituberculatum F.E.Fritsch \& M.F.Rich, Trans. Roy. Soc. S. Afr. 25: 181. 1937.

(Fig. 4G-J).

Cell dimensions - length $26-27 \mu \mathrm{m}$, breadth $22-23$ $\mu \mathrm{m}$, breadth of isthmus $7-8 \mu \mathrm{m}$.

Habitat - This variety was found generally associated with periphyton of Utricularia foliosa and Cabomba caroliniana. Conductivity $0.03\left( \pm 0.02 \mathrm{mS} . \mathrm{cm}^{-1}\right)$; dissolved oxygen $6.4\left( \pm 1.3 \mathrm{mg} . \mathrm{L}^{-1}\right) ; \mathrm{pH} 7.2( \pm 0.8)$; total dissolved solids 0.01 ( \pm 0.01$)$; water temperature $31.9\left( \pm 2.4^{\circ} \mathrm{C}\right)$; water transparency $0.67( \pm 0.12 \mathrm{~m})$.

Distribution - Africa, South-west Asia (India); South America: Brazil (first record).

Material examined - BRAZIL. Bahia: Andaraí, Pantanal dos Marimbus (Baiano), 23/V/2017, G.J.P.Ramos et al. s/n. (HUEFS 242429, HUEFS 242431); 18/II/2018, M.A.Santos et al. s/n. (HUEFS 253747, HUEFS 253750, HUEFS 253751); 09/IV/2018, M.A.Santos et al. s/n. (HUEFS 253757, HUEFS 253763); 12/VI/2018, M.A.Santos et al. s/n. (HUEFS 253769, HUEFS 253772).

Note - Cosmarium mamilliferum was described by Nordstedt (1870) based on specimens collected in the Lagoa Santa region, southeastern Brazil. Currently, there are seven varieties, generally reported for the Tropical region, including var. bituberculatum. During studies on material from Macina, French Sudan, Bourrelly (1957) proposed this variety based on Cosmarium bituberculatum. The cell outline of the Brazilian specimens is more similar to those reported by Grönblad \& Croasdale (1971, see Fig. 87) from Namibia. Based on the current known distribution, restricted to Africa, India, and Brazil, this variety may have been dispersed yet during the supercontinent Gondwana, when those regions were connected. However, further detailed phylogeographic studies should be performed to verify whether this theory is applied to var. bituberculatum and other endemic desmids from those regions.

17. Cosmarium mamilliferum var. madagascariense West \& G.S. West, Trans. Amer. Micros. Soc. 5: 57. 1895.

(Fig. 4K-O).

Cell dimensions - length 23-25.5 $\mu \mathrm{m}$, breadth 19.5$22 \mu \mathrm{m}$, breadth of isthmus 6.5-7.5 $\mu \mathrm{m}$.

Habitat - This variety was found generally associated with periphyton of Nymphaea amazonum and Cabomba caroliniana. Conductivity $0.06\left( \pm 0.03 \mathrm{mS} . \mathrm{cm}^{-1}\right)$; dissolved oxygen $8.2\left( \pm 0.8 \mathrm{mg} \cdot \mathrm{L}^{-1}\right) ; \mathrm{pH} 7.7( \pm 0.6)$; total dissolved solids $0.03( \pm 0.01)$; water temperature $30.5\left( \pm 3.4{ }^{\circ} \mathrm{C}\right)$; water transparency $0.74( \pm 0.08 \mathrm{~m})$.

Distribution - Africa, South America: Brazil (first record).

Material examined - BRAZIL. Bahia: Andaraí, Pantanal dos Marimbus (Baiano), 23/V/2017, G.J.P.Ramos et al. s/n. (HUEFS 241797, HUEFS 241798, HUEFS 242429); 18/ II/2018, M.A.Santos et al. s/n. (HUEFS 253746); 23/X/2018, M.A.Santos \& H.M.D.Oliveira s/n. (HUEFS 253788).

Note - The var. madagascariense is a rare taxon, with available records so far only for the African continent. It differs from the nominate variety in having larger cells with rounded margins, cell wall slightly thickened, and punctate.

18. Cosmarium mayori G.S.West, Mem. Soc. Sci. nat. Neuchatel 5(2): 1038. 1914.

(Fig. 4P-S).

Cell dimensions - length 32-33.5 $\mu$ m, breadth 27-27.5 $\mu \mathrm{m}$, breadth of isthmus 7.5-9.5 $\mu \mathrm{m}$.

Habitat - This variety was found associated with periphyton of Utricularia foliosa. Conductivity $0.02 \mathrm{mS} . \mathrm{cm}^{-1}$; dissolved oxygen $6.3 \mathrm{mg} \cdot \mathrm{L}^{-1}$; $\mathrm{pH}$ 6.6; total dissolved solids 0.01; water temperature $32^{\circ} \mathrm{C}$; water transparency $0.64 \mathrm{~m}$.

Distribution - South America: Colombia, Brazil (first record).

Material examined - BRAZIL. Bahia: Andaraí, Pantanal dos Marimbus (Baiano), 23/V/2017, G.J.P.Ramos et al. s/n. (HUEFS 241797); ); 18/II/2018, M.A.Santos et al. s/n. (HUEFS 253748).

Note - Cosmarium mayori is a rare taxon, known so far only for Colombia. It was described by West (1914) based on samples from Laguna de Ubaque, Eastern Andes, and posteriorly reported by Coesel (1992) also from the Andes region. Both records were from samples collected in high-altitude mountains ( $>2000 \mathrm{~m}$ ), whereas the Brazilian specimens occurred at a much lower altitude $(320 \mathrm{~m})$.

This species is very similar to Cosmarium areguense Borge, another taxon endemic to South America. We have found it also in the study area, and it is somewhat difficult to separate those species as they have the same cell outline and cell dimensions. The only morphological feature to separate both taxa is the cell wall arrangement; $C$. mayori differs in having cells with three rows of granules, which are surrounded by conspicuous pores, whereas the $C$. areguense has two rows, which are more curved.

19. Cosmarium miedzyrzecense var. monomazum Grönblad, Acta Soc. Fauna et Flora Fenn. 49(7): 40. 1921.

(Fig. 4T-U).

Cell dimensions - length $18-19 \mu \mathrm{m}$, breadth $13-14$ $\mu \mathrm{m}$, breadth of isthmus $4-5 \mu \mathrm{m}$. 
Habitat - This variety was found generally associated with periphyton of Utricularia foliosa and Cabomba caroliniana. Conductivity $0.04\left( \pm 0.02 \mathrm{mS} . \mathrm{cm}^{-1}\right)$; dissolved oxygen $6.3\left( \pm 0.7 \mathrm{mg} . \mathrm{L}^{-1}\right) ; \mathrm{pH} 6.8( \pm 0.4)$; total dissolved solids $0.02( \pm 0.02)$; water temperature $31.9\left( \pm 2^{\circ} \mathrm{C}\right)$; water transparency $0.73( \pm 0.11 \mathrm{~m})$.

Distribution - Europe (Finland), North America (USA); South America: Brazil (first record).

Material examined - BRAZIL. Bahia: Andaraí, Pantanal dos Marimbus (Baiano), 18/II/2018, M.A.Santos et al. s/n. (HUEFS 253747, HUEFS 253750); 09/IV/2018, M.A.Santos et al. s/n. (HUEFS 253756); 22/VIII/2018, M.A.Santos et al. s/n. (HUEFS 253778).

Note - The var. monomazum was proposed by Grönblad (1921) based on specimens from Finland. It differs from the nominate variety in having subtrapeziform semicells, retuse apices, and no granules at the isthmus region. Overall, this variety is quite rare, known only for its type-locality and Mississippi (USA) (Prescott \& Scott 1942). The only distinct morphological feature of Brazilian specimens is the scrobicles thickening, which is not as prominent as those reported from the northern hemisphere.

20. Cosmarium monomazum P.M.Lundell, Nova Acta Regiae Soc. Sci. Upsal. ser. 3, 8(2): 32. 1871.

(Fig. 4V-Y).

Cell dimensions - length $27 \mu \mathrm{m}$, breadth $31 \mu \mathrm{m}$, breadth of isthmus $11 \mu \mathrm{m}$.

Habitat - This species was found generally associated with periphyton of Utricularia foliosa and Cabomba caroliniana. Conductivity $0.04\left( \pm 0.02 \mathrm{mS} . \mathrm{cm}^{-1}\right)$; dissolved oxygen $6.6\left( \pm 1.6 \mathrm{mg} . \mathrm{L}^{-1}\right) ; \mathrm{pH} 7.4( \pm 0.6)$; total dissolved solids $0.02( \pm 0.01)$; water temperature $30.5\left( \pm 2.1^{\circ} \mathrm{C}\right)$; water transparency $0.69( \pm 0.19 \mathrm{~m})$.

Distribution - Cosmopolitan; South America: Argentina, Brazil (first record).

Material examined - BRAZIL. Bahia: Andaraí, Pantanal dos Marimbus (Baiano), 18/IX/2017, M.A.Santos et al. s/n. (HUEFS 241804); 18/II/2018, M.A.Santos et al. s/n. (HUEFS 253744, HUEFS 253745, HUEFS 253747, HUEFS 253748 , HUEFS 253750); 09/IV/2018, M.A.Santos et al. s/n. (HUEFS 253753, HUEFS 253756, HUEFS 253762, HUEFS 253763, HUEFS 253766); 12/VI/2018, M.A.Santos et al. s/n. (HUEFS 253768, HUEFS 253769, HUEFS 253772); 22/VIII/2018, M.A.Santos et al. s/n. (HUEFS 253781, HUEFS 253784).

Note - Cosmarium monomazum was described by Lundell (1871) based on material from Sweden. Although the reports are somewhat scarce in South America, it is considered a species with a cosmopolitan distribution. In Brazil, in addition to the typical variety reported in the present study, there are records of the two varieties, dimazum Willi Krieger and brasiliense (Kurt Först. \& Eckert) G.J.P.Ramos \& I.B.Oliveira, the latter also occurring in the study area.
21. Cosmarium orthostichum var. compactum West \& G.S.West, A monograph of the British Desmidiaceae. III: 169. 1908.

(Fig. 5A-C).

Cell dimensions - length 19-22 $\mu \mathrm{m}$, breadth 18-19 $\mu \mathrm{m}$, breadth of isthmus 6-7 $\mu \mathrm{m}$.

Habitat - This variety was found generally associated with periphyton of Utricularia foliosa. Conductivity 0.06 $\left( \pm 0.01 \mathrm{mS} . \mathrm{cm}^{-1}\right)$; dissolved oxygen $7.1\left( \pm 0.5 \mathrm{mg} \cdot \mathrm{L}^{-1}\right) ; \mathrm{pH}$ $6.8( \pm 0.3)$; total dissolved solids $0.02( \pm 0.007)$; water temperature $27.3\left( \pm 0.6^{\circ} \mathrm{C}\right)$; water transparency $0.60 \mathrm{~m}$.

Distribution - Europe, North America (USA, Canada); South America: Argentina, Brazil (first record).

Material examined - BRAZIL. Bahia: Andaraí, Pantanal dos Marimbus (Baiano), 23/V/2017, G.J.P.Ramos et al. s/n. (HUEFS 241798, HUEFS 242434).

Note - In Brazil, there are reports of nominate variety and var. pumilum P.Lundell so far. The var. compactum differs from the typical variety in having smaller cells, deeper constriction, sinus more narrowly linear, oblong-elliptic semicells, granules in 9 vertical and 3 or 4 horizontal series, vertical series upwardly divaricating, granules in the midregion of the semicells larger than those near the sides (West \& West 1908). In the study area, this variety is rare, occurring in general associated with Utricularia foliosa.

22. Cosmarium panamense Prescott, Trans. Amer. Micros. Soc 55: 504. 1936.

(Fig. 5D-F).

Cell dimensions - length $67 \mu \mathrm{m}$, breadth $53 \mu \mathrm{m}$, breadth of isthmus $18 \mu \mathrm{m}$.

Habitat - This species was found generally associated with periphyton of Utricularia foliosa. Conductivity 0.06 $\left( \pm 0.01 \mathrm{mS} . \mathrm{cm}^{-1}\right)$; dissolved oxygen $7.1\left( \pm 0.5 \mathrm{mg} \cdot \mathrm{L}^{-1}\right) ; \mathrm{pH}$ 6.8 ( \pm 0.3$)$; total dissolved solids $0.02( \pm 0.007)$; water temperature $27.3\left( \pm 0.6^{\circ} \mathrm{C}\right)$; water transparency $0.60 \mathrm{~m}$.

Distribution - Asia, Middle East, Central America (Panama); South America: Brazil (first confirmed record).

Material examined-BRAZIL. Bahia: Andaraí, Pantanal dos Marimbus (Baiano), 23/V/2017, G.J.P.Ramos et al. s/n. (HUEFS 241798, HUEFS 242434).

Note - Felisberto \& Rodrigues (2010) and Biolo \& Bicudo (2018) reported in checklists the occurrence of $C$. panamense for Brazil. Still, they did not provide taxonomic data such as description, cell dimensions, or figures, making the restudy of that species impossible, including the confirmation of its identification. Thus, the present record confirms the occurrence of $C$. panamense in Brazilian territory.

23. Cosmarium phaseolus var. subbireme Racib. Pam. Akad. Umiej. Krakowie, Mat.-Przyr. 17: 83. 1889.

(Fig. 5G-I). 
Cell dimensions - length $17 \mu \mathrm{m}$, breadth $20 \mu \mathrm{m}$, breadth of isthmus $5.5 \mu \mathrm{m}$.

Habitat - This variety was found associated with periphyton of Utricularia foliosa. Conductivity $0.02 \mathrm{mS} . \mathrm{cm}^{-1}$; dissolved oxygen $6.3 \mathrm{mg} . \mathrm{L}^{-1} ; \mathrm{pH}$ 6.6; total dissolved solids 0.01 ; water temperature $32^{\circ} \mathrm{C}$; water transparency $0.64 \mathrm{~m}$.

Distribution - Europe (France), Africa, South America: Brazil (first record).

Material examined - BRAZIL. Bahia: Andaraí, Pantanal dos Marimbus (Baiano), 23/V/2017, G.J.P.Ramos et al. s/n. (HUEFS 242431); 18/IX/2017, M.A.Santos et al. s/n (HUEFS 242479); 09/IV/2018, M.A.Santos et al. s/n (HUEFS 253763).

Note - The var. subbireme was proposed by Raciborski (1889) based on specimens associated with Chara coronata Ziz ex Bisch. (= Chara braunii C.C.Gmelin) from northern Italy. This variety differs from the nominate variety in having cells with larger median papillae, oblong semicells in apical view, and smooth cell wall. The few records of var. subbireme generally are from alkaline environments, i.e., Krieger \&
Gerloff (1962) reported specimens occurring at pH 8,5-8,8. In the Marimbus, that variety typically occurred under circumneutral conditions with $\mathrm{pH}$ ranging from 7 to 7.5 .

24. Cosmarium polygonum var. acutius Messik, Beitr. Geobot. Landesaufnahme Schweiz 24: 148. 1942.

(Fig. 5J-L).

Cell dimensions - length 9-11 $\mu \mathrm{m}$, breadth 9-11.5 $\mu \mathrm{m}$, breadth of isthmus $2.5-3 \mu \mathrm{m}$.

Habitat - This variety was found generally associated with periphyton of Utricularia foliosa and Cabomba caroliniana. Conductivity $0.03\left( \pm 0.02 \mathrm{mS} . \mathrm{cm}^{-1}\right)$; dissolved oxygen $6.5\left( \pm 1.3 \mathrm{mg} . \mathrm{L}^{-1}\right)$; $\mathrm{pH} 7( \pm 0.7)$; total dissolved solids $0.01( \pm 0.01)$; water temperature $31.4\left( \pm 2.2^{\circ} \mathrm{C}\right)$; water transparency $0.67( \pm 0.14 \mathrm{~m})$.

Distribution - Europe (Netherlands), South America: Brazil (first record).

Material examined - BRAZIL. Bahia: Andaraí, Pantanal dos Marimbus (Baiano), 18/II/2018, M.A.Santos et al.
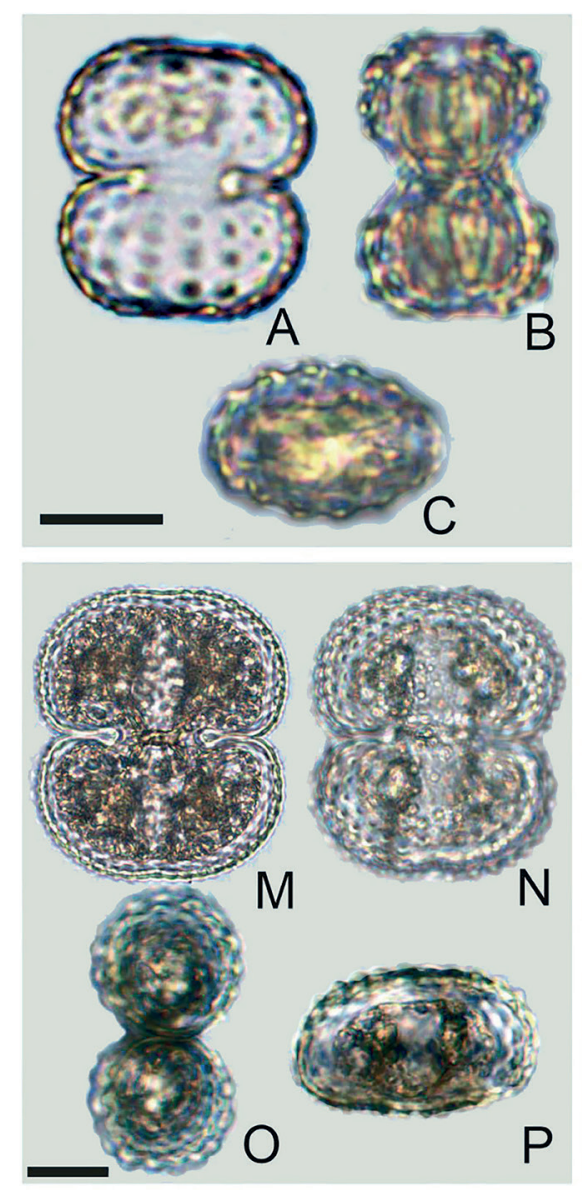
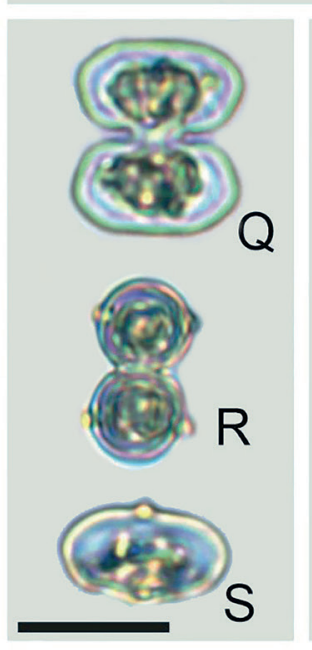
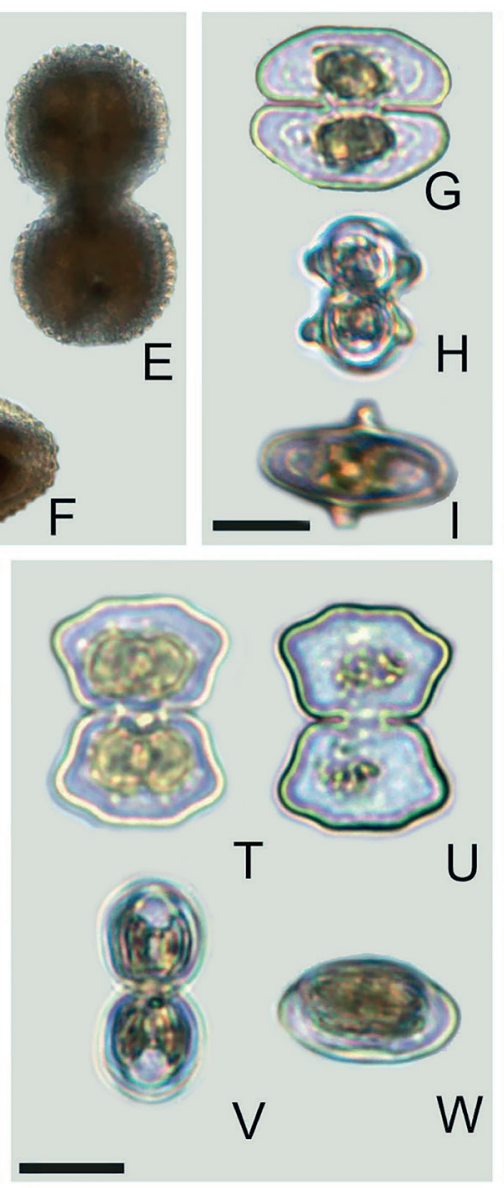

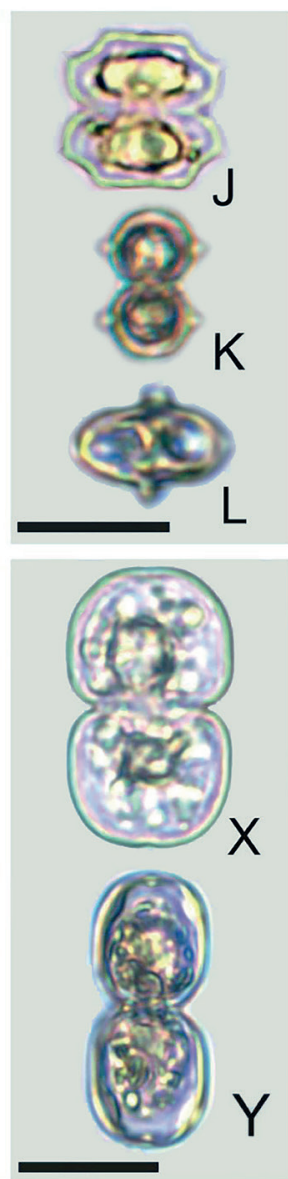

Figure 5. Cosmarium from the Pantanal dos Marimbus A-C. Cosmarium orthostichum var. compactum: frontal view (A), lateral view (B), apical view (E); D-F. Cosmarium panamense: frontal view (D), lateral view (E), apical view (F); G-I. Cosmarium phaseolus var. subbireme: frontal view $(\mathbf{G})$, lateral view $(\mathbf{H})$, apical view $(\mathbf{I})$; J-L. Cosmarium polygonum var. acutius: frontal view $(\mathbf{J})$, lateral view $(\mathbf{K})$ apical view $(\mathbf{L})$; M-P. Cosmarium pseudoinsigne: frontal view (M-N). lateral view $(\mathbf{O})$, apical view $(\mathbf{P})$; Q-S. Cosmarium pseudoprotuberans var. kossinskajae: frontal view (Q), lateral view (R), apical view (S); T-W. Cosmarium pseudoprotuberans var. retusiforme: frontal view (T-U), lateral view $(\mathbf{V})$, apical view $(\mathbf{P}) ; \mathbf{X}-\mathbf{Y}$. Cosmarium rectangulare var. cambrense: frontal view $(\mathbf{X})$, lateral view $(\mathbf{Y})$. Scale bar $10 \mu \mathrm{m}$. 
s/n. (HUEFS 253745, HUEFS 253747, HUEFS 253748, HUEFS 253751); 09/IV/2018, M.A.Santos et al. s/n. (HUEFS 253755, HUEFS 253756, HUEFS 253760); 12/VI/2018, M.A.Santos et al. s/n. (HUEFS 253766, HUEFS 253768, HUEFS 253769, HUEFS 253771, HUEFS 253772, HUEFS 253774); 23/X/2018, M.A.Santos \& H.M.D.Oliveira s/n. (HUEFS 253777, HUEFS 253778, HUEFS 253780, HUEFS 253779, HUEFS 253781, HUEFS 253783, HUEFS 253784).

Note - This taxon is similar to Cosmarium sinostegos and its varieties, differing by having cells with a wide blunt wart in the center, which is best visualized in apical view.

25. Cosmarium pseudoinsigne Prescott in G.W. Prescott, H.T. Croasdale, W.C. Vinyard, \& C. E. Bicudo, N. Amer. Desmids 2(3): 238. 1981.

(Fig. 5M-P).

Cell dimensions - length $45 \mu \mathrm{m}$, breadth $30 \mu \mathrm{m}$, breadth of isthmus $10 \mu \mathrm{m}$.

Habitat - This species was found associated with periphyton of Utricularia foliosa. Water temperature $27^{\circ} \mathrm{C}$; water transparency $2.2 \mathrm{~m}$.

Distribution - Europe, North America; South America: Argentina, Brazil (first record).

Material examined - BRAZIL. Bahia: Lençóis, Pantanal dos Marimbus (Remanso), 11/II/2012, G.J.P.Ramos \& C.A.Ribeiro s/n (1HUEFS 185427).

Note - The name Cosmarium pseudoinsigne was proposed by Prescott (Prescott et al. 1981), as the previous name (Cosmarium insigne Schmidle, nom. illeg. 1893) was considered invalid because there is another species with the same name described previously by Turner (1893). Thus, the taxon proposed by Schmidle (1893) is considered a later homonym (ICN Art. 53.1, Turland et al. 2018).

Cosmarium pseudoinsigne is somewhat rare in the study area, only reported in the northern region of Marimbus, known as "Marimbus do Remanso", located at the Municipality of Lençóis. Unlike the "Marimbus do Baiano", which the wetland is predominantly lentic, the Remanso area is generally characterized by a faster flow of the Santo Antonio River.

26. Cosmarium pseudoprotuberans var. kossinskajae Willi Krieger \& Gerloff, Die Gattung Cosmarium. Lieferung 2: 232. 1965 .

(Fig. 5Q-S).

Cell dimensions - length $13 \mu \mathrm{m}$, breadth $12 \mu \mathrm{m}$, breadth of isthmus $3.5 \mu \mathrm{m}$.

Habitat - This variety was found associated with periphyton of Utricularia foliosa. Conductivity $0.07 \mathrm{mS} . \mathrm{cm}^{-1}$; dissolved oxygen $7.5 \mathrm{mg} . \mathrm{L}^{-1}$; $\mathrm{pH}$ 6.5; total dissolved solids 0.03; water temperature $27^{\circ} \mathrm{C}$.

Distribution - Europe, Asia, Arctic, North America (Canada); South America: Argentina, Brazil (first record).
Material examined - BRAZIL. Bahia: Andaraí, Pantanal dos Marimbus (Baiano), 23/V/2017, G.J.P.Ramos et al. s/n (HUEFS 241798).

Note - The var. kossinskajae was proposed by Krieger \& Gerloff (1965) to accommodate minor forms of Cosmarium pseudoprotuberans and Cosmarium phaseolus Bréb. forma Schmidle (1898, 37, Taf. 1, Fig. 55). This variety differs from the nominate variety in having smaller cells with a median intumescence, sometimes almost rhombic.

27. Cosmarium pseudoprotuberans var. retusiforme F.E.Fritsch \& M.F.Rich, Trans. Roy. Soc. S.Afr. 25: 193. 1937.

(Fig. 5T-W).

Cell dimensions - length $19-20 \mu \mathrm{m}$, breadth $14-$ $15 \mu \mathrm{m}$, breadth of isthmus 4.5-5.5 $\mu \mathrm{m}$.

Habitat - This variety was found associated with periphyton of Utricularia foliosa, Nymphaea amazonum and Cabomba caroliniana. Conductivity $0.06\left( \pm 0.03 \mathrm{mS} . \mathrm{cm}^{-1}\right)$; dissolved oxygen $5.9\left( \pm 0.3 \mathrm{mg} . \mathrm{L}^{-1}\right)$; $\mathrm{pH} 6.4( \pm 0.4)$; total dissolved solids 0.03 ( \pm 0.02$)$; water temperature 28.3 $\left( \pm 1.1^{\circ} \mathrm{C}\right)$; water transparency $0.8( \pm 0.05 \mathrm{~m})$.

Distribution - Africa (South Africa); South America: Brazil (first record).

Material examined - BRAZIL. Bahia: Andaraí, Pantanal dos Marimbus (Baiano), 23/V/2017, G.J.P.Ramos et al. s/n (HUEFS 242431, HUEFS 242434); 22/VIII/2018, M.A.Santos et al. s/n (HUEFS 253778); 23/X/2018, M.A.Santos \& H.M.D.Oliveira (HUEFS 253791, HUEFS 253795).

Note - This variety was proposed by Fritsch \& Rich (1937) based on specimens from Africa. It differs from the nominate variety in having elliptical semicells in apical view without the median intumescence. Probably, the only country where this rare variety is known is South Africa (type locality). Therefore, the current record from Brazil expanses its geographic distribution also to South America.

28. Cosmarium rectangulare var. cambrense (W.B.Turner) West \& G.S. West, J. Bot. 34: 379. 1896.

(Fig. 5X-Y).

Cell dimensions - length $24 \mu \mathrm{m}$, breadth $13.5 \mu \mathrm{m}$, breadth of isthmus $5.5 \mu \mathrm{m}$.

Habitat - This variety was found associated with periphyton of Utricularia foliosa. Conductivity $0.06 \mathrm{mS} . \mathrm{cm}^{-1}$; dissolved oxygen $5.9 \mathrm{mg} . \mathrm{L}^{-1} ; \mathrm{pH}$ 6.9; total dissolved solids 0.03; water temperature $29.9^{\circ} \mathrm{C}$; water transparency $0.76 \mathrm{~m}$.

Distribution - Africa, Europe, Asia, Oceania; South America: Argentina, Brazil (first record). Material examined - BRAZIL. Bahia: Andaraí, Pantanal dos Marimbus (Baiano), 22/VIII/2018, M.A.Santos et al. s/n (HUEFS 253741).

Note - This variety was proposed by West $\&$ West (1896) during a taxonomic discussion on C. rectangulare 
var. africanum West \& G.S. West reported from Central Africa. The var. cambrense differs from the nominate variety in having cells relatively longer, the lower part of the cell sometimes is a little divergent, and the apex is often narrower. It was observed at the Brazilian specimens a thickening in the cell wall, well visible in the lateral view.

29. Cosmarium refringens W.R.Taylor, Pap. Mich. Acad. Sc. Arts Lett. 19: 265. 1934.

(Fig. 6A-C).

Cell dimensions - length $34 \mu \mathrm{m}$, breadth $22 \mu \mathrm{m}$, breadth of isthmus $7 \mu \mathrm{m}$.

Habitat - This species was found associated with periphyton of Utricularia foliosa, Nymphaea amazonum and Cabomba caroliniana. Conductivity $0.04\left( \pm 0.02 \mathrm{mS} . \mathrm{cm}^{-1}\right)$; dissolved oxygen $6.6\left( \pm 0.3 \mathrm{mg} \cdot \mathrm{L}^{-1}\right) ; \mathrm{pH} 7.4( \pm 0.6)$; total dissolved solids $0.02( \pm 0.01)$; water temperature 30.5 $\left( \pm 2.1^{\circ} \mathrm{C}\right)$; water transparency $0.7( \pm 0.17 \mathrm{~m})$.

Distribution - Europe, Asia, North America (Canada); South America: Argentina, Brazil (Mato Grosso - ? , - Bahia - first confirmed record).

Material examined - BRAZIL. Bahia: Andaraí, Pantanal dos Marimbus (Baiano), 23/V/2017, G.J.P.Ramos et al. s/n. (HUEFS 242431); 18/IX/2017, M.A.Santos et al. s/n (HUEFS 242474); 19/VIII/2011, G.J.P.Ramos \& C.W.N. Moura s/n (HUEFS 185352); 18/II/2018, M.A.Santos et al. s/n. (HUEFS 253744, HUEFS 253751); 09/IV/2018, M.A.Santos et al. s/n. (HUEFS 253755, HUEFS 253754, HUEFS 253757, HUEFS 253759); ); 12/VI/2018, M.A.Santos et al. s/n. (HUEFS 253765, HUEFS 253766, HUEFS 253768, HUEFS 253771, HUEFS 253772, HUEFS 253774); 22/VIII/2018, M.A.Santos et al. s/n. (HUEFS 253780).

Note - The occurrence of this species in Brazil was reported by De-Lamonica-Freire \& Heckman (1996) and Freitas \& Loverde-Oliveira (2013), both for the state of Mato Grosso. However, there is no taxonomic data in these papers, such as description, cell dimensions, or figures to confirm the identification of this species. Thus, the taxon from Bahia represents the first confirmed taxonomic record of $C$. refringens for Brazil.

30. Cosmarium regnellii var. chondrophorum Skuja, Nova Acta R. Soc. Sc. Upsal., ser. 4, 14(5): 139. 1949.

(Fig. 6D-G).

Cell dimensions - length $15-16 \mu \mathrm{m}$, breadth 11 $12 \mu \mathrm{m}$, breadth of isthmus 3-4 $\mu \mathrm{m}$.

Habitat - This species was found associated with periphyton of Utricularia foliosa and Nymphaea amazonum. Conductivity $0.015\left( \pm 0.024 \mathrm{mS} . \mathrm{cm}^{-1}\right)$; dissolved oxygen 6.5 ( \pm 1 mg. $\left.\mathrm{L}^{-1}\right) ; \mathrm{pH} 6.7$ ( \pm 0.7); total dissolved solids 0.01 ( \pm 0.012$)$; water temperature $29.3\left( \pm 3.8^{\circ} \mathrm{C}\right)$; water transparency $0.76( \pm 0.1 \mathrm{~m})$.
Distribution - Africa, Middle East, Asia, South America: Argentina, Brazil (first record).

Material examined - BRAZIL. Bahia: Andaraí, Pantanal dos Marimbus (Baiano), 23/V/2017, G.J.P.Ramos et al. s/n. (HUEFS 242423); 18/IX/2017, M.A.Santos et al. s/n. (HUEFS 242471); 18/II/2018, M.A.Santos et al. s/n. (HUEFS 253746); 23/X/2018, M.A.Santos \& H.M.D.Oliveira (HUEFS 253788, HUEFS 253791).

Note - This variety differs primarily from the nominate variety in having larger cells with a central wart. Our SEM analysis also revealed that the cell wall is entirely scrobiculate, therefore another important morphological feature distinct from the typical variety, which has a smooth cell wall.

31. Cosmarium regnesi var. tritum West, J. Linn. Soc. London. Botany 29: 149. 1892.

(Fig. 6H-I).

Cell dimensions - length $11 \mu \mathrm{m}$, breadth $10.5 \mu \mathrm{m}$, breadth of isthmus $5 \mu \mathrm{m}$.

Habitat - This variety was found associated with periphyton of Utricularia foliosa. Conductivity $0.01 \mathrm{mS} . \mathrm{cm}^{-1}$; dissolved oxygen $6.0 \mathrm{mg} \cdot \mathrm{L}^{-1} ; \mathrm{pH}$ 7.2; total dissolved solids 0.01; water temperature $27.8^{\circ} \mathrm{C}$; water transparency $1.4 \mathrm{~m}$.

Distribution - Europe, Asia; South America, Brazil (first record).

Material examined - BRAZIL. Bahia: Andaraí, Pantanal dos Marimbus (Baiano), 12/VI/2018, M.A.Santos et al. s/n. (HUEFS 253772).

Note - It differs from the nominate variety by having no granules and cells more robust. This variety was relatively rare in the study area, and just a few cells were observed occurring associated with Utricularia foliosa.

32. Cosmarium subgranatum var. borgei Willi Krieger, Ber. Deutsch. Bot. Ges. 61: 269. 1944.

(Fig. 6J-L).

Cell dimensions - length $21-23 \mu \mathrm{m}$, breadth 14 $15 \mu \mathrm{m}$, breadth of isthmus 5-5.5 $\mu \mathrm{m}$.

Habitat - This variety was found generally associated with periphyton of Utricularia foliosa and Cabomba caroliniana. Conductivity $0.02\left( \pm 0.02 \mathrm{mS} . \mathrm{cm}^{-1}\right)$; dissolved oxygen $6.8\left( \pm 0.8 \mathrm{mg} . \mathrm{L}^{-1}\right) ; \mathrm{pH} 7( \pm 0.7)$; total dissolved solids $0.01( \pm 0.01)$; water temperature $28.3\left( \pm 2.3^{\circ} \mathrm{C}\right)$; water transparency $0.8( \pm 0.11 \mathrm{~m})$.

Distribution - Europe, Asia; South America, Brazil (first record).

Material examined - BRAZIL. Bahia: Andaraí, Pantanal dos Marimbus (Baiano), 09/XII/2011, G.J.P.Ramos \& C.A.Ribeiro s/n (HUEFS 185390); 23/V/2017, G.J.P.Ramos et al. s/n (HUEFS 242423, HUEFS 242434, HUEFS 242437); 18/II/2018, M.A.Santos et al. s/n. (HUEFS 253747); 09/ IV/2018, M.A.Santos et al. s/n. (HUEFS 253753). 

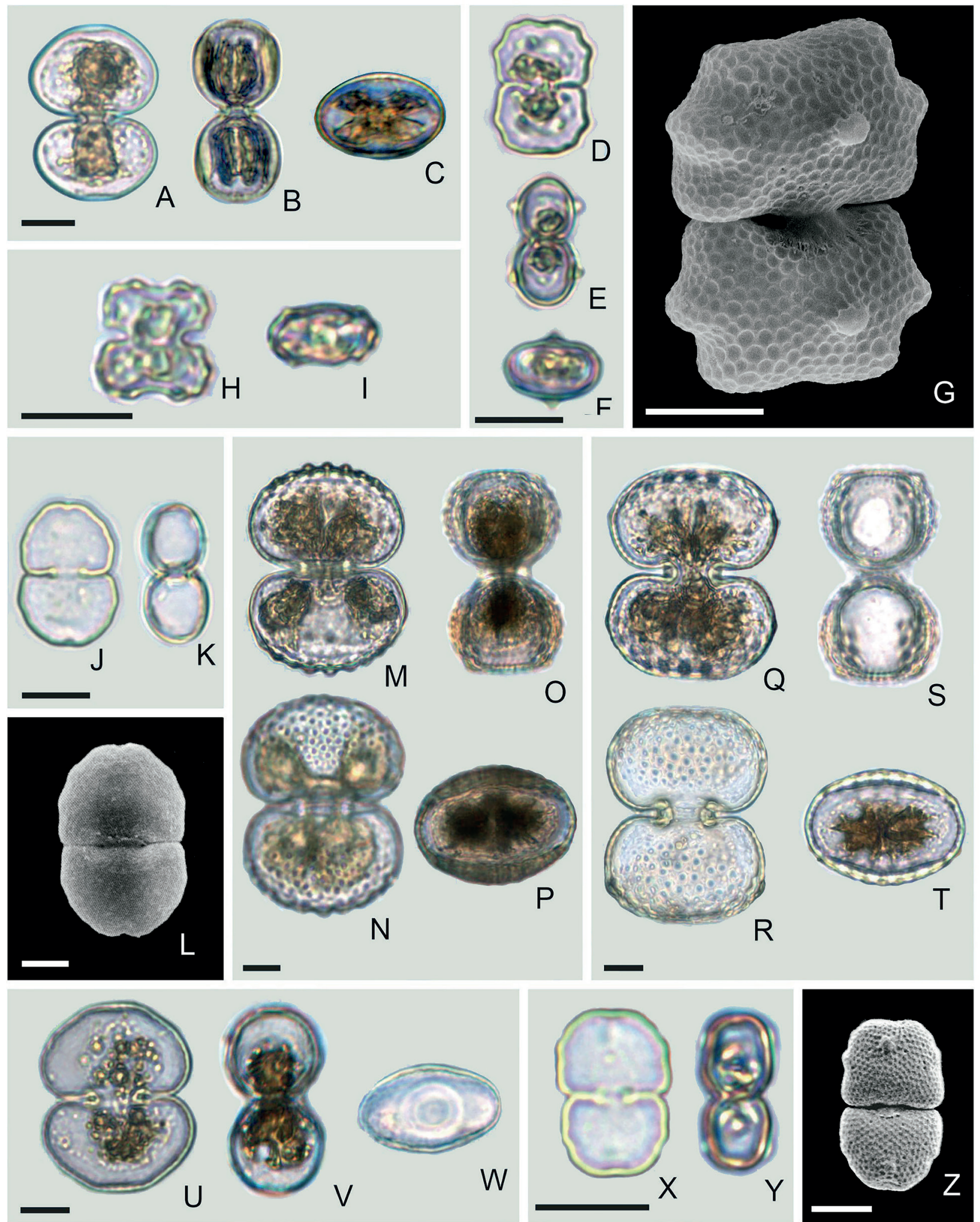

S
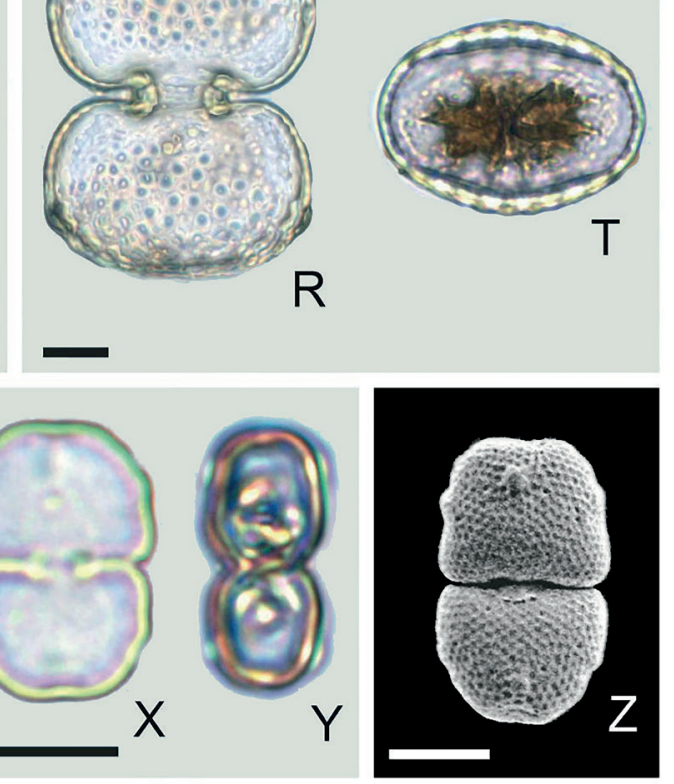

Figure 6. Cosmarium from the Pantanal dos Marimbus A-C. Cosmarium refringens: frontal view (A), lateral view (B), apical view (C); D-G. Cosmarium regnellii var. chondrophorum: frontal view (D), lateral view (E), apical view (F), Detail of the cell wall in SEM (G); H-I. Cosmarium regnesi var. tritum: frontal view $(\mathbf{H})$, apical view $(\mathbf{I})$; J-L. Cosmarium subgranatum var. borgei: frontal view (J, L), lateral view (K), Detail of the cell wall in SEM (L); M-P. Cosmarium subnudiceps: frontal view (M-N), lateral view $(\mathbf{O})$, apical view $(\mathbf{P})$; $\mathbf{Q}-\mathbf{T}$. Cosmarium subnudiceps var. angulare: frontal view $(\mathbf{Q}-\mathbf{R})$, lateral view $(\mathbf{S})$, apical view $(\mathbf{T})$; $\mathbf{U}-\mathbf{W}$. Cosmarium subphaseolus: frontal view $(\mathbf{U})$, lateral view $(\mathbf{V})$ apical view $(\mathbf{W}) ; \mathbf{X}-\mathbf{Z}$. Cosmarium subreinschii var. tholiforme: frontal view $(\mathbf{X}, \mathbf{Z})$, lateral view $(\mathbf{Y})$, Detail of the cell wall in SEM (Z). Scale bar $10 \mu \mathrm{m}$ (LM), $5 \mu \mathrm{m}$ (SEM). 
Note - Krieger (1944) proposed the var. borgei, which was validated years later by Krieger \& Gerloff (1965) based on the phenotypical variation of six taxa, including some intraspecific representatives of Cosmarium granatum Bréb. ex Ralfs, C. laeve Rabenh. and C. meneghinii Bréb. ex Ralfs. This variety differs from the nominate variety in having semicircular semicells with margins crenate (10 roughly equal waves, as described by Krieger 1944). The Brazilian specimens generally have slightly crenate margins, not always well visible in LM. Among the taxa transferred to var. borgei, the taxon from Marimbus resembles more the morphotype designed by Krieger (1932) as "Cosmarium laeve var. septentrionale Wille".

33. Cosmarium subnudiceps West \& G.S.West, J. Linn. Soc., London. Botany 33: 306. 1898.

(Fig. 6M-P).

Cell dimensions - length $54 \mu \mathrm{m}$, breadth $43 \mu \mathrm{m}$, breadth of isthmus $12 \mu \mathrm{m}$.

Habitat - This species was found associated with periphyton of Utricularia foliosa and Cabomba caroliniana. Conductivity $0.04\left( \pm 0.03 \mathrm{mS} . \mathrm{cm}^{-1}\right)$; dissolved oxygen 6.3 ( \pm 1 mg. $\left.\mathrm{L}^{-1}\right) ; \mathrm{pH} 6.8$ ( \pm 0.3); total dissolved solids 0.02 ( \pm 0.018$)$; water temperature $30.1\left( \pm 3.8^{\circ} \mathrm{C}\right)$; water transparency $0.75( \pm 0.08 \mathrm{~m})$.

Distribution - North America (USA, Canada), Europe (Italy); South America: (Argentina, Bolivia), Brazil (first record).

Material examined - BRAZIL. Bahia: Andaraí, Pantanal dos Marimbus (Baiano), 23/V/2017, G.J.P.Ramos et al. s/n (HUEFS 242434, HUEFS 242437); 18/II/2018, M.A.Santos et al. s/n. (HUEFS 253748); 09/IV/2018, M.A.Santos et al. s/n. (HUEFS 253759, HUEFS 253760); 22/VIII/2018, M.A.Santos et al. s/n. (HUEFS 253778).

Note - This species is characterized in having ellipsoid semicells with cell wall ornamented by granules surrounded by scrobicles, which are variable from circular to triangular. It was described by West \& West (1898) from material collected in Laconia, New Hampshire (USA). Couté \& Tell (1981), based on specimens from Argentina, provided for the first time SEM images for this species, evidencing the heterogeneous pattern of cell wall including smooth part, granules and scrobicles, and detailed dimensions of those ornamentations.

34. Cosmarium subnudiceps var. angulare Scott \& Grönblad, Acta Soc. Sc. Fenn. N. s. B, 2(8): 23. 1957.

(Fig. 6Q-T).

Cell dimensions - length 55-60 $\mu \mathrm{m}$, breadth 42-46 $\mu \mathrm{m}$, breadth of isthmus 13-14 $\mu \mathrm{m}$.

Habitat - This species was found associated with periphyton of Utricularia foliosa and Cabomba caroliniana. Conductivity $0.03\left( \pm 0.018 \mathrm{mS} . \mathrm{cm}^{-1}\right)$; dissolved oxygen 6.5 $\left( \pm 1 \mathrm{mg} . \mathrm{L}^{-1}\right) ; \mathrm{pH} 7( \pm 0.7)$; total dissolved solids $0.01( \pm 0.015)$; water temperature $31.4\left( \pm 1.5^{\circ} \mathrm{C}\right)$; water transparency 0.66 $( \pm 0.15 \mathrm{~m})$.
Distribution - North America (USA), South America (Argentina), Brazil (first record).

Material examined - BRAZIL. Bahia: Andaraí, Pantanal dos Marimbus (Baiano), 23/V/2017, G.J.P.Ramos et al. s/n (HUEFS 242434); 18/II/2018, M.A.Santos et al. s/n. (HUEFS 253745, HUEFS 253748, HUEFS 253751); 09/ IV/2018, M.A.Santos et al. s/n. (HUEFS 253753, HUEFS 253757, HUEFS 253766, HUEFS 253774).

Note - The var. angulare was described by Scott \& Grönblad (1957) based on material from Florida (USA). It differs from the nominate variety in having subhexagonal semicells, with cell wall ornamented by granules interspersed with triangular or circular scrobiculations connected by lines forming triangles. This variety is similar to Cosmarium hexagonum Nordst.; however, this species differs by having elliptical-hexagonal semicells, convex margins, and cell wall finely punctate with subapical granules.

35. Cosmarium subphaseolus Kouwets, Arch. Hydrobiol. Suppl. 137 (Algol. Stud. 101): 44. 2001.

(Fig. 6U-W).

Cell dimensions - length 35-37 $\mu \mathrm{m}$, breadth 30-31 $\mu \mathrm{m}$, breadth of isthmus 7-8 $\mu \mathrm{m}$.

Habitat - this species was found associated with periphyton of Utricularia foliosa. Water temperature 25 ${ }^{\circ} \mathrm{C}$; water transparency $2.2 \mathrm{~m}$.

Distribution - Europe (France); Brazil (first record).

Material examined - BRAZIL. Bahia: Lençóis, Pantanal dos Marimbus (Remanso), 11/II/2012, G.J.P.Ramos \& C.A.Ribeiro s/n (HUEFS 185418).

Note-Cosmarium subphaseolus is a rather rare species, described by Kouwets (2001) based on specimens from three France areas. So far, it was only known in those areas. Its occurrence in northeastern Brazil is interesting because evidencing that the species also is adapted to conditions of the Tropical Region. The Brazilian specimens have precisely the same morphological pattern, although slightly larger, from those reported by Kouwets (2001). According to this author, this species should be compared with $C$. phaseolus Bréb. ex Ralfs and C. subtumidum Nordst. In addition to these taxa, we recommend comparing $C$. retusiforme var. major Gutw., which differs by having cells with upper lateral margin slightly concave.

36. Cosmarium subreinschii var. tholiforme (W.R.Taylor) G.W.Prescott, Syn. N. Amer. Desmids 2(3): 312. 1981.

三Cosmarium impressulum f. tholiforme W.R.Taylor, Pap. Mich. Acad. Sci. Arts Lett. 19: 255. 1934.

(Fig. 6X-Z).

Cell dimensions - length $14 \mu \mathrm{m}$, breadth $8 \mu \mathrm{m}$, breadth of isthmus $3.5 \mu \mathrm{m}$.

Habitat - This species was found associated with periphyton of Utricularia foliosa, Nymphaea amazonum and 
Cabomba caroliniana. Conductivity $0.04\left( \pm 0.02 \mathrm{mS} . \mathrm{cm}^{-1}\right)$; dissolved oxygen $6.6\left( \pm 0.3 \mathrm{mg} . \mathrm{L}^{-1}\right) ; \mathrm{pH} 7.4( \pm 0.6)$; total dissolved solids $0.02( \pm 0.01)$; water temperature 30.5 $\left( \pm 2.1^{\circ} \mathrm{C}\right)$; water transparency $0.7( \pm 0.17 \mathrm{~m})$.

Distribution - North America (Canada); Asia (Myanmar), South America, Brazil (first record). Material examined - BRAZIL. Bahia: Andaraí, Pantanal dos Marimbus (Baiano), 23/V/2017, G.J.P.Ramos et al. s/n. (HUEFS 242423); 18/IX/2017, M.A.Santos et al. s/n (HUEFS 242479); 18/II/2018, M.A.Santos et al. s/n. (HUEFS 253744, HUEFS 253743, HUEFS 253745, HUEFS 253746, HUEFS 253747); 09/IV/2018, M.A.Santos et al. s/n. (HUEFS 253753, HUEFS 253754, HUEFS 253755, HUEFS 253757 , HUEFS 253759, HUEFS 253760, HUEFS 253762, HUEFS 253761, HUEFS 253763); 12/VI/2018, M.A.Santos et al. s/n. HUEFS (253765, HUEFS 253768, HUEFS 253771,
HUEFS 253772, HUEFS 253774, HUEFS 253775); $22 /$ VIII/2018, M.A.Santos et al. s/n. (HUEFS 253777, HUEFS 253778, HUEFS 253781).

Note - It differs from the nominate variety in having smaller cells, with apices slightly concave and scrobiculate cell wall. The Brazilian specimens have some variations only regarding the position of verrucae, which are generally in the subapical region.

37. Cosmarium subspeciosum var. argentinense Couté \& Tell, Beth. Nova Hedwigia 68: 94. 1981.

(Fig. 7A-F).

Cell dimensions - length $76 \mu \mathrm{m}$, breadth $58 \mu \mathrm{m}$, breadth of isthmus $16 \mu \mathrm{m}$.

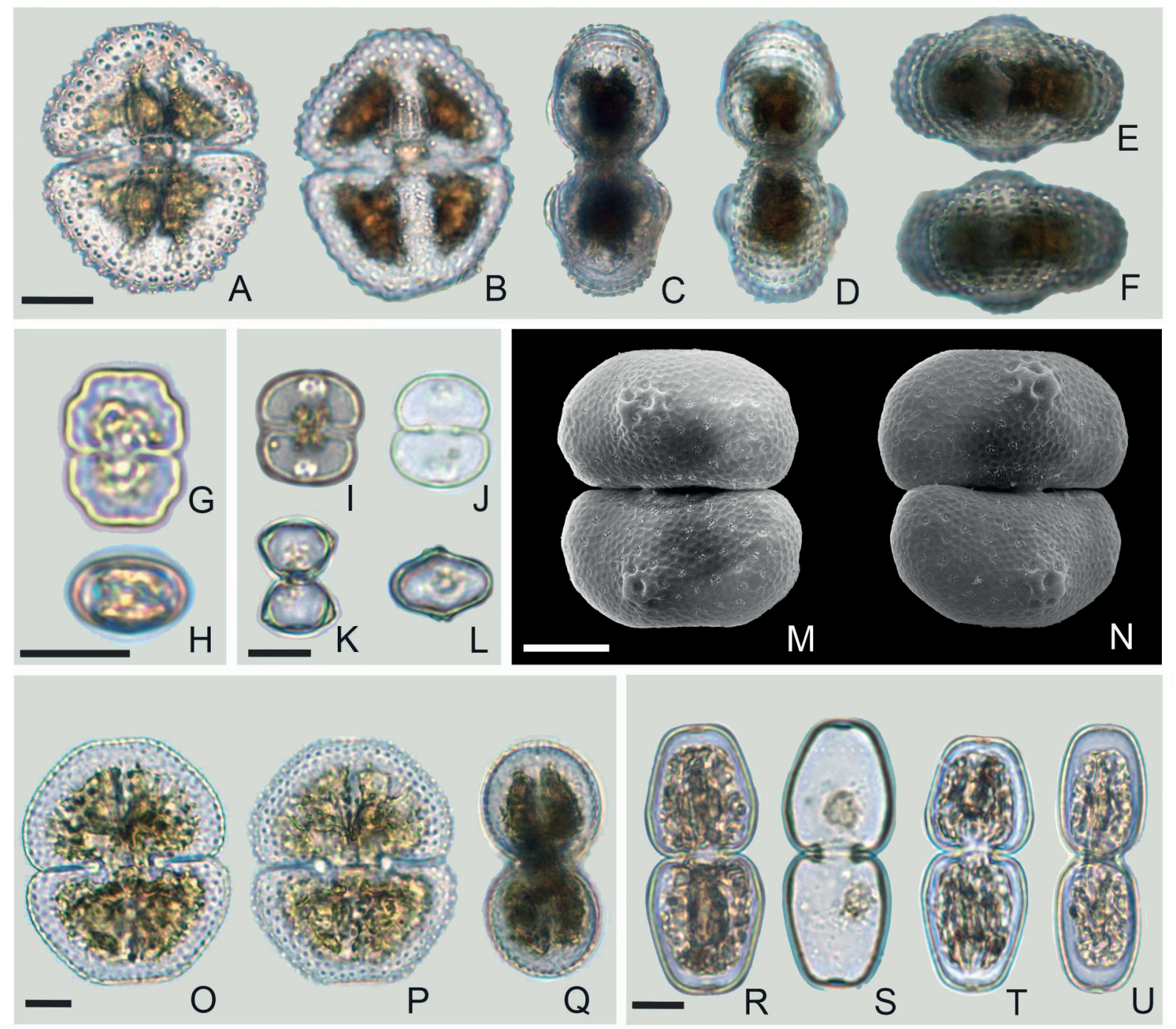

Figure 7. Cosmarium from the Pantanal dos Marimbus A-F. Cosmarium subspeciosum var. argentinense: frontal view (A-B), lateral view (C-D), apical view (E-F); G-H. Cosmarium trilobulatum var. minus: frontal view (G), apical view (H); I-N. Cosmarium tumidum var. inflatum: frontal view (I-J), lateral view (K), apical view (L), Detail of the cell wall in SEM (M-N); P-Q. Cosmarium vexatum var. rotundatum: frontal view (O-P), lateral view (Q); R-U. Cosmarium zonatum var. angustum: frontal view (R-T), lateral view (U). Scale bar $10 \mu \mathrm{m}$ (LM), $5 \mu \mathrm{m}$ (SEM). 
Habitat - This species was found associated with periphyton of Utricularia foliosa. Conductivity $0.05 \mathrm{mS} . \mathrm{cm}^{-1}$; dissolved oxygen $6.8 \mathrm{mg} \cdot \mathrm{L}^{-1}$; $\mathrm{pH} 7$; total dissolved solids 0.02; water temperature $27.8^{\circ} \mathrm{C}$; water transparency $0.6 \mathrm{~m}$

Distribution - South America (Argentina); Brazil (first record).

Material examined - BRAZIL. Bahia: Andaraí, Pantanal dos Marimbus (Baiano), 23/V/2017, G.J.P.Ramos et al. s/n. (HUEFS 241798).

Note - The var. argentinense was described by Couté \& Tell (1981) based on material from Corrientes, Argentina. It differs from the nominate variety in having triangular semicells. Overall, this a rather rare taxon, known so far only for its type-locality and probably endemic to South America. The Brazilian specimens are identical to those from Argentina, although they seem to have cells with fewer rows of intramarginal granules (up to three).

38. Cosmarium trilobulatum var. minus (Wille) Willi Krieger \& Gerloff, Die Gattung Cosmarium. Lieferung 1: 100. 1962.

$\equiv$ Cosmarium trilobulatum f. minus Wille, Forth. Vid.Selsk. Christiania 1880(11):32 (1880).

(Fig. 7G-H).

Cell dimensions - length $76 \mu \mathrm{m}$, breadth $58 \mu \mathrm{m}$, breadth of isthmus $16 \mu \mathrm{m}$.

Habitat - This species was found associated with periphyton of Utricularia foliosa. Conductivity $0.01 \mathrm{mS} . \mathrm{cm}^{-1}$; dissolved oxygen $6 \mathrm{mg} \cdot \mathrm{L}^{-1} ; \mathrm{pH}$ 7.2; total dissolved solids 0.01 ; water temperature $28^{\circ} \mathrm{C}$; water transparency $2.4 \mathrm{~m}$.

Distribution - Europe; South America: French Guiana, Argentina, Brazil (first record).

Material examined - BRAZIL. Bahia: Andaraí, Pantanal dos Marimbus (Baiano), 12/VI/2018, M.A.Santos et al. s/n. (HUEFS 253772).

Note - It differs from the nominate variety in having smaller semicells. Due to this, it might be easily confused with representatives of Cosmarium regnellii Wille. Still, this latter species differs in having a divergent lower side margin and concave upper side margin.

39. Cosmarium tumidum var. inflatum (Schmidle) Willi Krieger \& Gerloff, Die Gattung Cosmarium. Lieferung 1: 58. 1962.

$\equiv$ Cosmarium tumidum f. inflatum Schmidle, Bih. K. Svenska Vet.-Akad. Vetyx handl. 24(Afd. III): 24 (1898).

(Fig. 7I-N).

Cell dimensions - length $16 \mu \mathrm{m}$, breadth $15 \mu \mathrm{m}$, breadth of isthmus $4 \mu \mathrm{m}$.

Habitat - This species was found associated with periphyton of Utricularia foliosa and Cabomba caroliniana. Conductivity $0.06\left( \pm 0.02 \mathrm{mS} . \mathrm{cm}^{-1}\right)$; dissolved oxygen 7.5 ( $\left.\pm 2.1 \mathrm{mg} . \mathrm{L}^{-1}\right) ; \mathrm{pH} 7$ ( \pm 0.7); total dissolved solids 0.02
( \pm 0.01); water temperature $30.3\left( \pm 2.9{ }^{\circ} \mathrm{C}\right)$; water transparency $0.75( \pm 0.14 \mathrm{~m})$.

Distribution - Europe (Sweden, Austria), North America, Asia (India); South America: Brazil (first record).

Material examined - BRAZIL. Bahia: Andaraí, Pantanal dos Marimbus (Baiano) 23/V/2017, G.J.P.Ramos et al. s/n. (HUEFS 242434); 18/IX/2017, M.A.Santos et al. s/n (HUEFS 242474); 18/II/2018, M.A.Santos et al. s/n. (HUEFS 253750, HUEFS 253760, HUEFS 253762); 22/VIII/2018, M.A.Santos et al. s/n. (HUEFS HUEFS 253783).

Note - It differs from the nominate variety in having subapical swelling more pronounced, from clearer pores interspersed, while the remaining cell wall is slightly scrobiculate. In LM, sometimes the swelling seems two verrucae surrounded by scrobicles. This is the first time that this variety is reported for South America.

40. Cosmarium vexatum var. rotundatum Messik., Beitr. Geobot. Landesaufnahme Schweiz 24: 159. 1942.

(Fig. 7O-Q).

Cell dimensions - length $49-55 \mu \mathrm{m}$, breadth $42-46 \mu \mathrm{m}$, breadth of isthmus $4 \mu \mathrm{m}$.

Habitat - This species was found associated with periphyton of Utricularia foliosa, Nymphaea amazonum and Cabomba caroliniana. Conductivity $0.06\left( \pm 0.02 \mathrm{mS} . \mathrm{cm}^{-1}\right)$; dissolved oxygen $6.6\left( \pm 1.5 \mathrm{mg} . \mathrm{L}^{-1}\right)$; pH $6.9( \pm 0.4)$; total dissolved solids $0.02( \pm 0.008)$; water temperature 31.4 $\left( \pm 1.3^{\circ} \mathrm{C}\right)$; water transparency $0.74( \pm 0.17 \mathrm{~m})$.

Distribution - North America, Europe; South America: Brazil (first record).

Material examined - BRAZIL. Bahia: Andaraí, Pantanal dos Marimbus (Baiano), 18/II/2018, M.A.Santos et al. s/n. (HUEFS 253741, HUEFS 253745, HUEFS 253747); 09/ IV/2018, M.A.Santos et al. s/n. (HUEFS 253752, HUEFS 253762); 23/X/2018, M.A.Santos \& H.M.D.Oliveira s/n (HUEFS 253790); 04/XII/2018, M.A.Santos \& E.Santos s/n (HUEFS 253805).

Note - It differs from the nominate variety in having cells with basal side margins more rounded, granules subacute, and some granules on the isthmus. From the present record, besides the nominate variety, Cosmarium vexatum is represented in Brazil by two varieties: var. rotundatum and var. lacustre Messik.

41. Cosmarium zonatum var. angustum Grönblad \& Scott, Acta Bot. Fenn. 58: 35. 1958.

(Fig. 7R-U).

Cell dimensions - length $50-55 \mu \mathrm{m}$, breadth $22-24 \mu \mathrm{m}$, breadth of isthmus 7.5-8.5 $\mu \mathrm{m}$.

Habitat - This species was found associated with periphyton of Utricularia foliosa, Nymphaea amazonum and Cabomba caroliniana. Conductivity $0.06\left( \pm 0.03 \mathrm{mS} . \mathrm{cm}^{-1}\right)$; dissolved oxygen $6.2\left( \pm 0.9\right.$ mg. $\left.\mathrm{L}^{-1}\right) ; \mathrm{pH} 7( \pm 0.4)$; total 
dissolved solids $0.01( \pm 0.017)$; water temperature 29.9 $\left( \pm 2.1^{\circ} \mathrm{C}\right)$; water transparency $0.76( \pm 0.13 \mathrm{~m})$.

Distribution - Europe (Netherlands), Africa (Sudan, Uganda, Kongo); South America: Brazil (first record).

Material examined - BRAZIL. Bahia: Andaraí, Pantanal dos Marimbus (Baiano), 29/VI/ 2011, G.J.P.Ramos \& C.A.Ribeiro s/n (HUEFS 178376); 20/VIII/2011, G.J.P.Ramos \& C.W.N. Moura s/n (HUEFS 185359); 26/X/2011, G.J.P.Ramos \& C.A.Ribeiro s/n (HUEFS 185368); 18/IX/2017, M.A.Santos et al. s/n (HUEFS 241804); 18/ II/2018, M.A.Santos et al. s/n. (HUEFS 253741, HUEFS 253749); 09/IV/2018, M.A.Santos et al. s/n. (HUEFS 253755, HUEFS 253756); 12/VI/2018, M.A.Santos et al. s/n. (HUEFS 253765); 12/VI/2018, M.A.Santos et al. s/n. (HUEFS 253772, HUEFS 253773); 22/VIII/2018, M.A.Santos et al. s/n. (HUEFS 253778, HUEFS 253779, HUEFS 253780).

Note - It differs from the nominate variety in having cells more elongated, narrowed toward the apices, which are ellipsoid in apical view. This is the first record of this variety in the American continent.

42. Cosmarium imperiale G.J.P.Ramos \& C.W.N.Moura, sp. nov.

(Fig. 8A-K).

Cells 1.1. to 1.2 times longer than broad, deeply constricted, sinus open. Semicells subrectangular to subtrapeziform, elliptic in apical view, circular in lateral view. Cell wall ornamented with a crown of granules on the subapical margin, 3 granules surrounded by scrobicles on the median face of the semicell, and 1 granule on the middle of lateral margin. Chloroplast axial with 2 pyrenoids per semicell.

Cell dimensions - length $64-66.5 \mu \mathrm{m}$, width 55.5$57 \mu \mathrm{m}$, breadth of isthmus 17-18.5 $\mu \mathrm{m}$, thickness 35-35.5 $\mu \mathrm{m}$.

Type - BRAZIL. Bahia: Andaraí, Pantanal dos

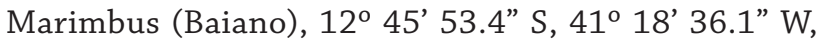
23/V/2017, G.J.P.Ramos, F.M.Costa \& C.W.N.Moura s/n (Holotype, HUEFS 241798! [pro parte]). Population partially illustrated here in LM (Fig 8A-K). Etymology - The pattern of the subapical row of granules resembles that of jewels of an imperial crown.

Distribution - Endemic to Chapada Diamantina, Bahia, Brazil.

Habitat - The new species was found associated with periphyton of Utricularia foliosa. Conductivity $0.06( \pm 0.007$ $\left.\mathrm{mS} . \mathrm{cm}^{-1}\right)$; dissolved oxygen $7.8\left( \pm 0.5 \mathrm{mg} . \mathrm{L}^{-1}\right) ; \mathrm{pH} 7.1( \pm 0.8)$; total dissolved solids 0.05 ( \pm 0.03$)$; water temperature 28.7 $\left( \pm 2.4^{\circ} \mathrm{C}\right.$ ); water transparency $0.75 \mathrm{~m}$; $\mathrm{PO}_{4}-\mathrm{P} 0.02 \mathrm{mg} \mathrm{L}^{-1}$; $\mathrm{NO}_{2}-\mathrm{N} 0.02 \mathrm{mg} \mathrm{L}^{-1}$; Silicate $0.33 \mathrm{mg} \mathrm{L}^{-1}$.

Note - This new species is one of the rarest Cosmarium taxa found in the Marimbus. It is morphologically close to $C$. cyathiforme West \& G.S.West; however, the latter differs in that it has no granule on the middle of the lateral margin, nor scrobicles on the wall, besides being half the cell size (length $35 \mu \mathrm{m}$, width $34 \mu \mathrm{m}$, isthmus $7.5 \mu \mathrm{m}$, thickness $21 \mu \mathrm{m}$ ). There are some other taxa with similar cell outline, differing especially in the ornamentation arrangement of the cell wall, such as Cosmarium subnudiceps var. angulare, and Cosmarium hexagonum. In addition to morphology, Cosmarium imperiale and all those mentioned taxa have the same distribution as they are endemic to the American continent.

\section{Richness of Cosmarium}

The taxonomic richness of Cosmarium was highest in Utricularia foliosa with 38 taxa, followed by Cabomba caroliniana (20) and Nymphaea amazonum (10). In terms of the species richness in the different macrophytes studied, those on $U$. foliosa contained 17 exclusive taxa, followed by C. caroliniana (two) and N. amazonum (one). Only six taxa occurred in all three macrophyte species: Cosmarium zonatum var. angustum, $C$. vexatum var. rotundatum, $C$. subreinschii var. tholiforme, C. anisochondrum var. isthmolatum, C. refringens, C. pseudoprotuberans var. retusiforme. The list of all taxa of Cosmarium and the richness in each macrophyte species is represented in the Venn diagram (Fig. 9).

\section{Ecological aspects}

Overall, throughout 2018 the water conditions were characterized by having circumneutral $\mathrm{pH}$, with low electrical conductivity and low concentration of total suspended solids, besides being generally well oxygenated. The highest water transparency values were recorded in the dry months (April, August, and October), whereas the highest depth values were in the rainy months (February, June, and December). The limnological variables of samples from 2018 are summarized in the Table 1.

Aiming to verify the relation between the environmental variables and the taxa of Cosmarium, we have performed the Redundancy Analysis (RDA) (Fig. 10, Tab. 2). The analysis explained $17.3 \%$ of the observed variation in the first two axes ( $12.8 \%$ on-axis 1 and $4.5 \%$ on-axis 2$)$, but only the axis 1 was significant $(\mathrm{p}<0.01)$. The species and sampling units on axis 1 were ordered in the function of the temperature and depth ( $r=0.75$ and $r=0.54$, respectively). Although not significant, axis 2 represented the variation in rainfall in 2018, with the sampling units in the rainy months (February, June, and December) being ordered on the positive side of the axis, and those in the dry months (April, August, and October), mostly, on the negative side. The taxa Cosmarium bireme var. barbadense, Cosmarium mamilliferum var. madagascariense, Cosmarium mayori, Cosmarium subnudiceps, and Cosmarium subnudiceps var. angulare were associated with higher temperature values, being grouped on the negative side of the axis 1 ( $r>-0.5)$. Cosmarium zonatum var. angustum was correlated mainly with depth $(r>0.4)$. Mostly the taxa showed the highest densities in the months with low precipitation when the conductivity and transparency of the water were greater. 


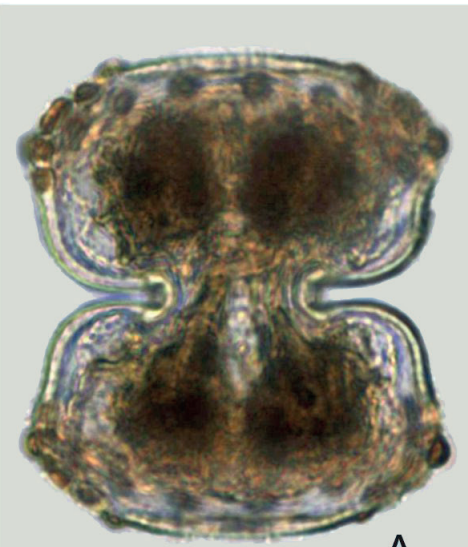

A

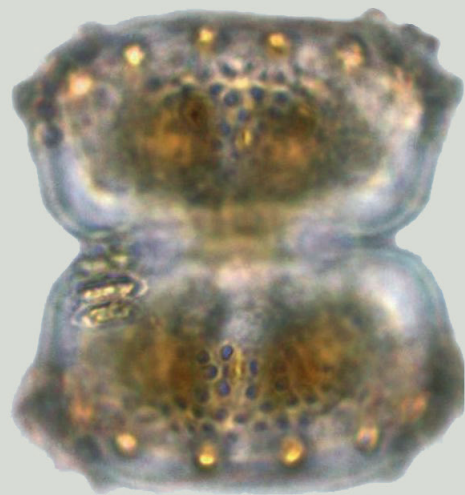

$\mathrm{D}$

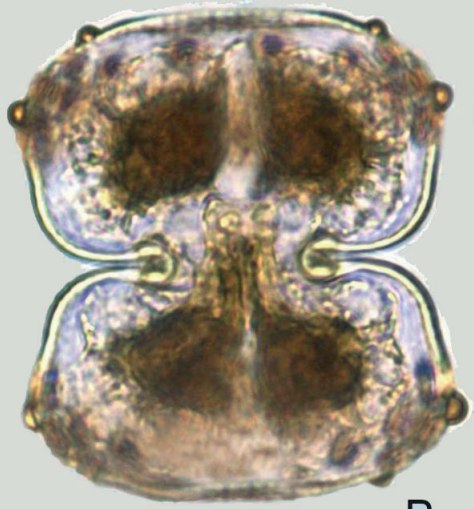

B

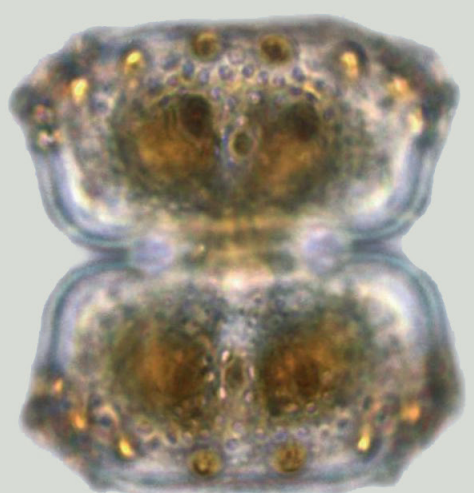

E
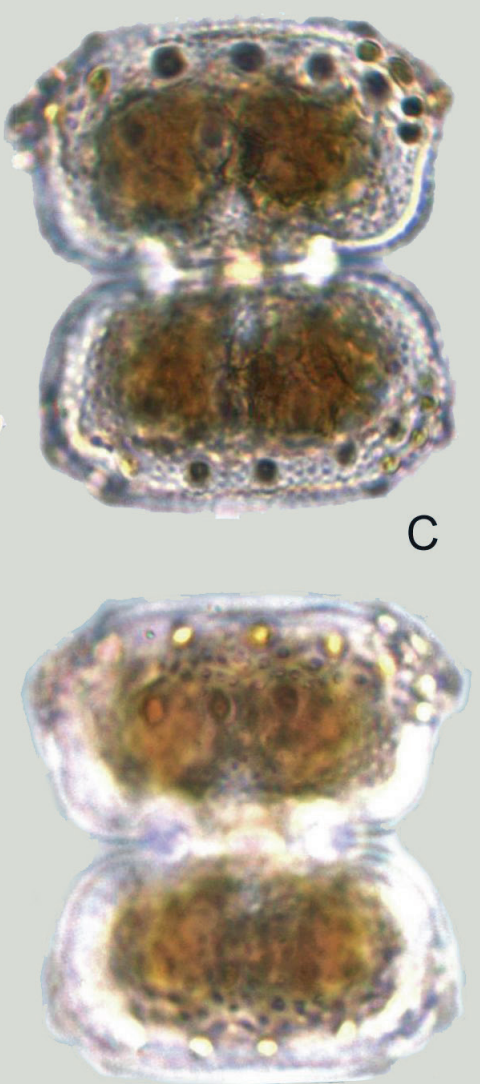

F
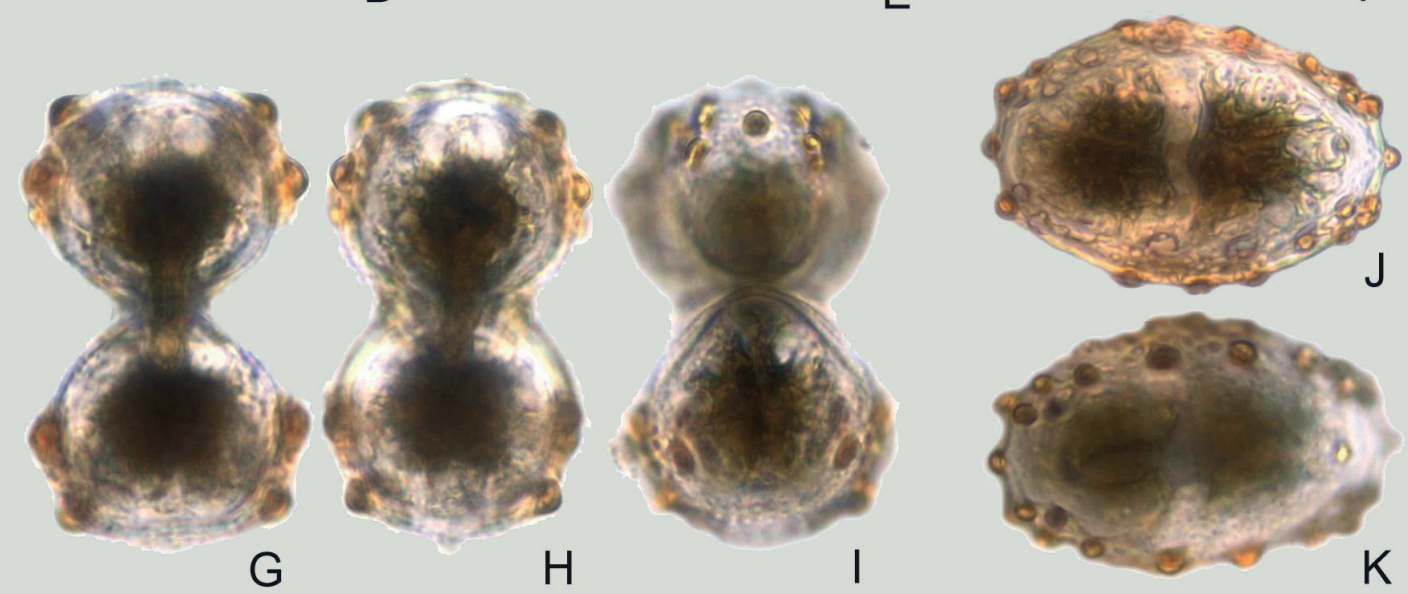

Figure 8. Cosmarium imperiale sp. nov. A-F. frontal view; G-I. lateral view; J-K. apical view. Scale bar $10 \mu \mathrm{m}$.

Table 1. Mean values and standard deviation of limnological variables during 2018 in the Pantanal dos Marimbus (Baiano), Bahia, Brazil.

\begin{tabular}{|c|c|c|c|c|c|c|}
\hline \multirow{2}{*}{ Limnological variables } & \multicolumn{5}{|c|}{2018} \\
\cline { 2 - 7 } Depth $(\mathrm{m})$ & February & April & June & August & October & December \\
\hline Dissolved oxygen $\left(\mathrm{mg} . \mathrm{L}^{-1}\right)$ & $1.6 \pm 0.2$ & $2.0 \pm 0.5$ & $2.4 \pm 0.04$ & $1.9 \pm 0.3$ & $1.9 \pm 0.3$ & $3.5 \pm 0.7$ \\
\hline Electric conductivity $\left(\mathrm{mS} . \mathrm{cm}^{-1}\right)$ & $6.1 \pm 0.5$ & $8.3 \pm 1.0$ & $6.1 \pm 0.5$ & $8.4 \pm 1.7$ & $6.5 \pm 0.7$ & $7.0 \pm 1.4$ \\
\hline $\mathrm{pH}$ & $0.04 \pm 0.02$ & $0.6 \pm 0.1$ & $0.02 \pm 0.01$ & $0.07 \pm 0.0$ & $0.03 \pm 0.02$ & $0.00 \pm 0.00$ \\
\hline Total dissolved solids $(\mathrm{ppt})$ & $6.7 \pm 0.3$ & $7.3 \pm 0.4$ & $7.7 \pm 1.0$ & $7.6 \pm 0.3$ & $6.8 \pm 0.9$ & $6.6 \pm 2.0$ \\
\hline Total precipitation $(\mathrm{mm})$ & 109.1 & 6.0 & 106.4 & 18.5 & 11.4 & 181.5 \\
\hline Water temperature $\left({ }^{\circ} \mathrm{C}\right)$ & $31.3 \pm 1.0$ & $32.5 \pm 1.4$ & $28.3 \pm 1.4$ & $28.6 \pm 0.3$ & $26.9 \pm 1.0$ & $29.9 \pm 0.8$ \\
\hline Water transparency $(\mathrm{cm})$ & $60.6 \pm 17.3$ & $77.1 \pm 7.0$ & $61.0 \pm 9.8$ & $92.8 \pm 10.2$ & $83.1 \pm 8.3$ & $51.1 \pm 3.9$ \\
\hline
\end{tabular}




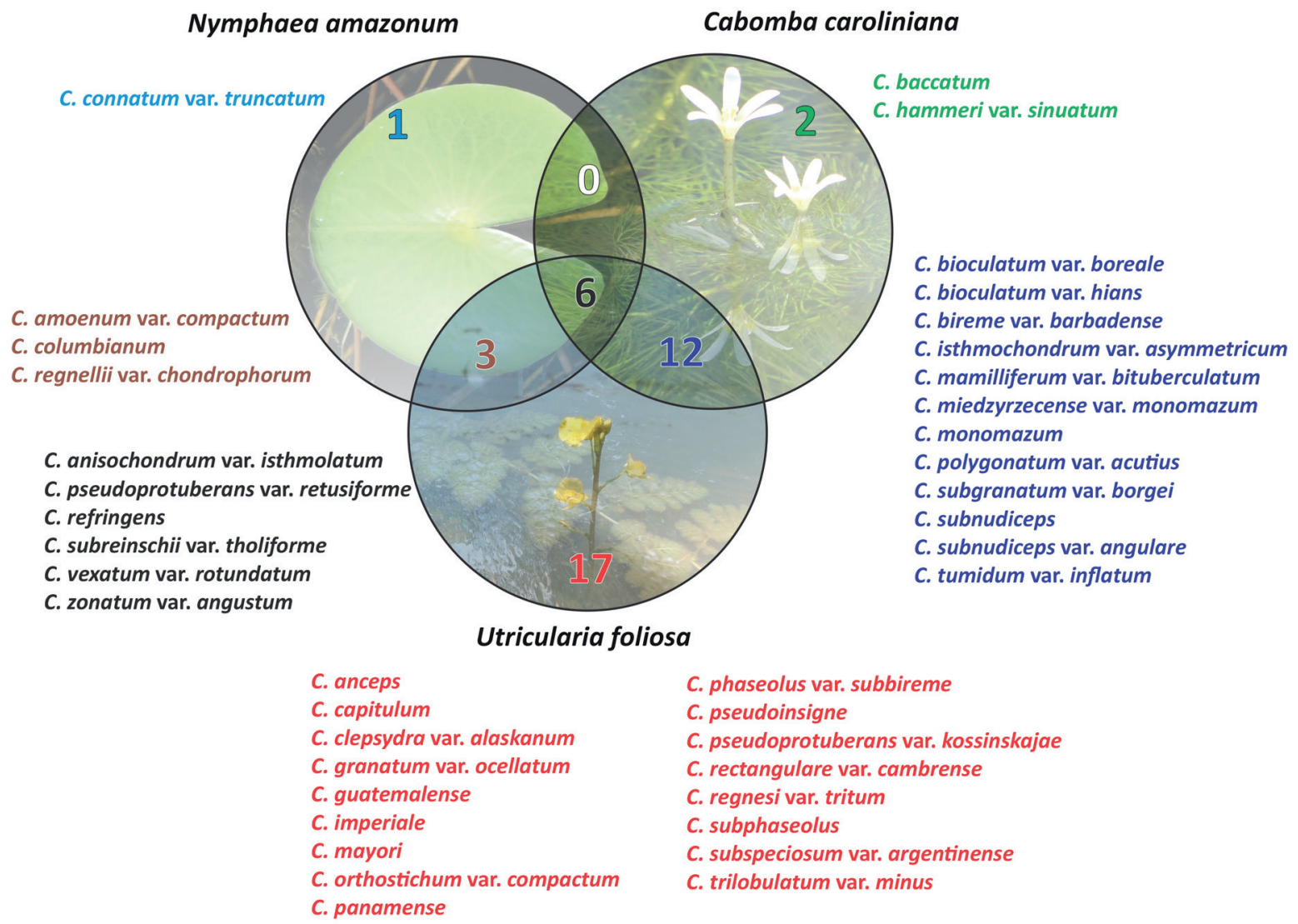

Figure 9. Venn diagram showing the number of taxa and taxa occurring in three aquatic macrophytes (Nymphaea amazonum, Cabomba caroliniana, Utricularia foliosa) from the Pantanal dos Marimbus.

\section{Conservation}

The Pantanal dos Marimbus comprises a wide floodplain area within Caatinga domain (Fig. 11A, B), and is subdivided into four areas (Fig. 11C), from north region to south: (1) Marimbus do Remanso, (2) Marimbus da Fazenda Velha, (3) Marimbus do Ferreira, (4) Marimbus do Baiano. These wetlands are currently partially protected by gubernatorial decrees and incorporated into Marimbus-Iraquara EPA and Chapada Diamantina National Park (PARNA Chapada Diamantina). However, Pantanal dos Marimbus is not fully protected since only the first three regions are officially within environmental conservation areas: Marimbus do Remanso is into the Marimbus-Iraquara EPA, whereas Marimbus da Fazenda Velha and Ferreira are areas within PARNA Chapada Diamantina. Hence, the south region (Marimbus do Baiano), where most of the present study samples were gathered, is the only one officially unprotected (Fig 11B). Some papers are reporting the rich biodiversity from that area, including plants and fishes (Moura \& Marques 2007; França et al. 2010; Lima et al. 2012), as well as a number of endemic and rare species of algae, especially chlorophytes and desmids (Ramos et al. 2015; 2020; Costa et al. 2018; 2020). Currently, that area has been quite used also for tourist activities, such as Stand-Up paddle or paddle yourself with Canadian canoes. Thus, we have suggested the expansion of the Marimbus-Iraquara EPA limits to cover the Marimbus do Baiano, as this area harbors outstanding aquatic biodiversity and should also be a priority for conservation (Fig. 11B).

\section{Conclusion}

The genus Utricularia is considered an excellent substrate to the occurrence of periphytic desmids, especially by having leaves that are highly cropped (Hall \& McCourt 2017). Since they are finely dissected, the leaves of this macrophyte favor the heterogeneity of habitat and provide a larger area for colonization of algae, including desmids (McAbendroth et al. 2005; Santos et al. 2013). The morphology of its leaves facilitates the penetration and availability of light for the adhered algae, contributing to the development of that community (Cattaneo et al. 1998). Many interesting desmids, including rare and new species, have been reported occurring associated with those plants in Brazil since the 18th century (Nordstedt 1878; Lemmermann 1914; Förster 1964; Menezes et al. 2013). In the present study, the highest richness of Cosmarium in Utricularia foliosa (38 taxa: 17 are exclusive) confirms the important role of these plants in forming the periphytic community. Most of the Cosmarium taxa found in this macrophyte has some type of ornamentation in the cell wall, mainly granules; 
Table 2. Scores and codes of the Cosmarium taxa obtained by tb-RDA.

\begin{tabular}{|c|c|c|c|}
\hline Taxa & Code & RDA 1 & RDA 2 \\
\hline Cosmarium amoenum var. compactum West \& G.S.West & $\mathrm{Cac}$ & -0.30 & 0.10 \\
\hline C. anceps P.Lundell & Can & -0.15 & -0.15 \\
\hline C. anisochondrum var. isthmolatum Thérézien & Cai & -0.11 & 0.31 \\
\hline C. bioculatum var. boreale (Børgesen) Willi Krieg. \& Gerloff & $\mathrm{Cbb}$ & -0.17 & 0.22 \\
\hline C. bioculatum var. hians West \& G.S.West & $\mathrm{Cbh}$ & 0.64 & -0.11 \\
\hline C. bireme var. barbadense G.S.West & $\mathrm{Cbi}$ & -0.54 & -0.01 \\
\hline C. clepsydra var. alaskanum Croasdale & Cca & 0.23 & 0.11 \\
\hline C. columbianum G.S.West & Cco & 0.05 & -0.20 \\
\hline C. connatum var. truncatum West & $\mathrm{Ccn}$ & -0.15 & -0.15 \\
\hline C. hammeri var. sinuatum Borge & Chs & 0.28 & 0.06 \\
\hline C. isthmochondrum var. asymmetricum Scott \& Grönblad & Cia & -0.42 & -0.29 \\
\hline C. subgranatum var. borgei Willi Krieg. & $\mathrm{Csb}$ & 0.12 & -0.20 \\
\hline C. mamilliferum var. bituberculatum (F.E.Fritsch \& M.F.Rich) Bourrelly & $\mathrm{Cmb}$ & -0.31 & 0.18 \\
\hline C. mamilliferum var. madagascariense West \& G.S.West & $\mathrm{Cmm}$ & -0.52 & -0.11 \\
\hline C. mayori G.S.West & Cmay & -0.50 & 0.05 \\
\hline C. miedzyrzecense var. monomazum Grönblad & Cmied & -0.46 & 0.13 \\
\hline C. monomazum P.Lundell & Cmon & -0.48 & 0.18 \\
\hline C. orthostichum var. compactum West \& G.S.West & $\mathrm{Coc}$ & 0.03 & 0.07 \\
\hline C. phaseolus var. subbireme Racib. & Cpha & -0.07 & -0.01 \\
\hline C. polygonum var. acutius Messik. & Cpoly & -0.35 & -0.21 \\
\hline C. pseudoprotuberans var. retusiforme F.E.Fritsch \& M.F.Rich & Cpr & 0.08 & -0.28 \\
\hline C. rectangulare var. cambrense (W.B.Turner) West \& G.S. West & Crec & -0.32 & -0.02 \\
\hline C. refringens W.R.Taylor & Cref & -0.16 & 0.53 \\
\hline C. regnellii var. chondrophorum Skuja & Creg & -0.01 & -0.12 \\
\hline C. imperiale sp. nov. & Cimp & -0.19 & -0.13 \\
\hline C. regnesi var. tritum West & Crt & 0.11 & 0.14 \\
\hline C. subnudiceps var. angulare Scott \& Grönblad & Csa & -0.59 & 0.07 \\
\hline C. subnudiceps West \& G.S.West & Csubn & -0.58 & -0.08 \\
\hline C. subreinschii var. tholiforme (W.R.Taylor) Prescott & Csubr & -0.24 & -0.22 \\
\hline C. trilobulatum var. minus (Wille) Willi Krieg. \& Gerloff & Ctri & -0.15 & -0.15 \\
\hline C. tumidum var. inflatum (Schmidle) Willi Krieg. \& Gerloff & Cti & -0.09 & -0.30 \\
\hline C. vexatum var. rotundatum Messik. & Cvr & 0.11 & -0.29 \\
\hline C. zonatum var. angustum Grönblad \& Scott & Cza & 0.42 & 0.19 \\
\hline
\end{tabular}

therefore, those cell structures might also have contributed to adherence of the taxa in those plants.

Some rare Cosmarium taxa known so far only in their type localities had their distribution enlarged to Brazil or South America, such as Cosmarium pseudoprotuberans var. retusiforme, C. subspeciosum var. argentinense, C. subphaseolus. The former has not been reported since 1937 from Africa, the second one since 1981(Argentina), whereas C. subphaseolus since 2001 (France). In addition to enlarge their known distribution, these new records help understand the current conservation status and which habitat conditions these species are currently occurring.

Regarding ecological aspects, the oligotrophic conditions and low conductivity were favorable for the development of Cosmarium and other desmids in the Marimbus. The water transparency was somewhat low due to the high concentration of humic substances giving the brown aspect to the water. This color is typical of the most aquatic ecosystems from the Chapada Diamantina region, including the Santo Antônio River, which is considered the main river that supplies the Pantanal dos Marimbus.
The desmids form a highly diverse group, especially in tropical regions, where they usually have high densities (Coesel 1996). These algae need higher temperatures $\left(25-30{ }^{\circ} \mathrm{C}\right)$ for their ideal growth. Some genera, such as Cosmarium, can adapt quickly to adverse conditions of temperature and light, which makes them stand out, especially in warm and transparent waters (Coesel \& Wardenaar 1990; Stamenkovic $\&$ Hanelt 2017). This explains the higher density of Cosmarium taxa in the drier months because, besides interfering in the hydrodynamics and turbidity of the aquatic body, changing the availability of light, the precipitation can also cause the detachment and loading of periphytic algae, impairing the development of the community (Cavati \& Fernandes 2008, Domitrovic et al. 2013).

From the present study, our knowledge on desmids from South America has been expanded, especially in the Caatinga domain, the only biome exclusive from Brazil, which now has 55 taxa known of Cosmarium. Our results also have implications for the biogeographic studies on the group since some taxa were known only to other continents such as Europe and Africa, as well as other areas from South 


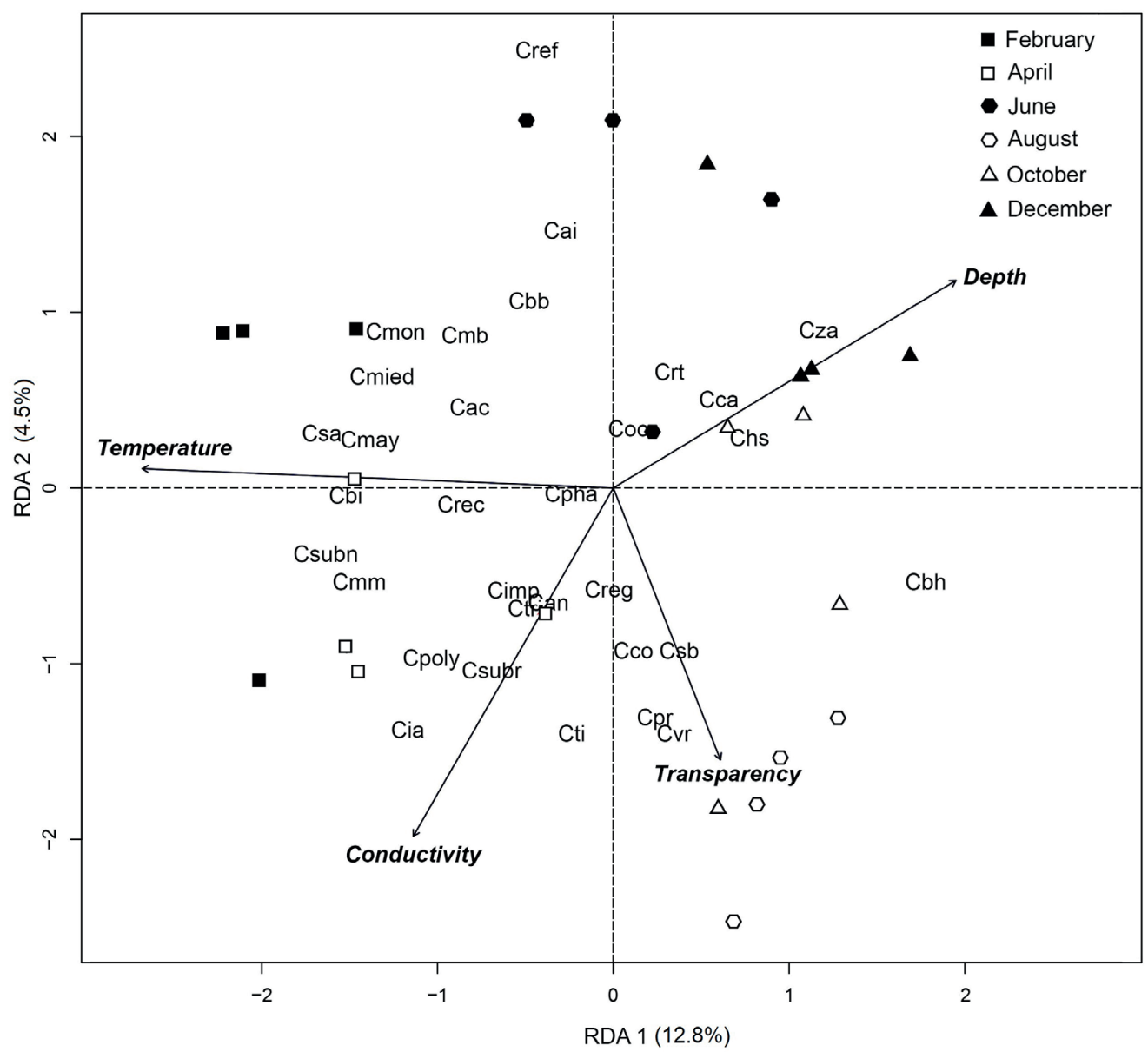

Figure 10. Ordination diagram yielded by tb-RDA for the complete selected model with limnological variables and Cosmarium taxa occurring in the Pantanal dos Marimbus (Baiano) during 2018. Dry months (April, August and October), rainy months (February, June and December).
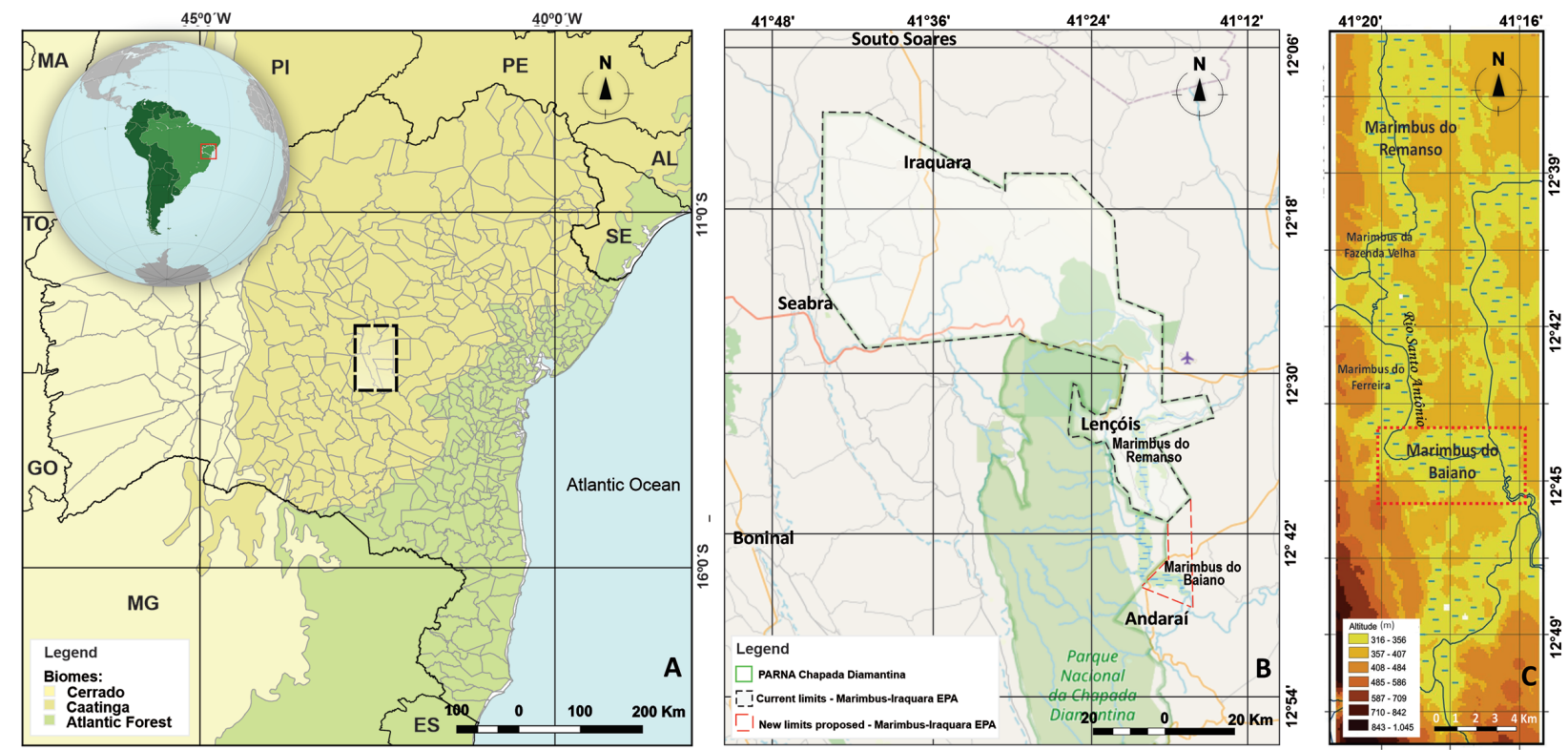

Figure 11. A. Map of the Pantanal dos Marimbus region within the Caatinga domain. B. Limits of the Marimbus-Iraquara EPA, Chapada Diamantina National Park (Parna Chapada Diamantina), and new limits proposed for the Marimbus-Iraquara EPA (modified from OpenStreetMap 2020) C. Four areas of the Pantanal dos Marimbus (modified from França et al. 2010). 
America. It is highly recommended to expand the limits of the Marimbus-Iraquara EPA to cover the "Marimbus do Baiano", an area with rich aquatic biodiversity that is not included in the EPA neither Chapada Diamantina National Park. Also, more taxonomic studies should be performed at other areas from the Caatinga, as other interesting desmid species might occur in that biome. The taxonomic data analyzed here corroborate the theory that the Chapada Diamantina is one of the main biodiversity centers within the Caatinga domain.

\section{Acknowledgements}

This study was financed in part by the Coordenação de Aperfeiçoamento Pessoal de Nível Superior - Brasil (CAPES) - Finance Code 001. We are grateful to Projeto Flora da Bahia (483909/2012-2), to Conselho Nacional de Desenvolvimento Científico e Tecnológico (CNPq) for financial support of the Projeto Ecológico de Longa Duração (PELD - Chapada Diamantina, MCT/CNPq n ${ }^{\circ} 59 / 2009$ ) and for the fellowships granted to GJPR (150380/2019-4) and MAS (141734/2017-5).

\section{References}

Bicudo CEM, Menezes M. 2017. Gêneros de algas de águas continentais do Brasil: chave para identificação e descrições. 3rd. edn. São Carlos, RiMa Editora.

Biolo S, Bicudo CEM. 2018. Checklist of the genus Cosmarium (Zygnematophyceae, Streptophyta) from Brazil. Biodiversity International Journal 2: 452-454.

Blanchet FG, Legendre P, Borcard D. 2008. Forward selection of explanatory variables. Ecology 89: 2623-2632.

Borge O. 1899. Ueber tropische und subtropische SüsswasserChlorophyceen. Bihang til Kongliga Svenska Vetenskaps-Akademiens Handlingar 24: 1-33.

Borge O. 1903. Die Algen der ersten Regnellschen Expedition. II. Desmidiaceen. Arkiv för Botanik 1: 71-138.

Borge O. 1918. Die von Dr. A. Löfgren in São Paulo gessammelten Süsswasseralgen. Arkiv för Botanik 15: 1-108.

Borge O. 1925. Die von Dr. F.C. Hoehne während der Expedition RooseveltRondon gesammelten Süsswassernalgen. Arkiv for Botanik 19: 1-56.

Bourrelly P. 1957. Algues d'eau douce du Soudan Francais, region du Macina (A.O.F.). Bulletin de l' Institut français d'Afrique Noire, Série A, Sciences Naturelles 19: 1047-1102.

Brook AJ. 1981. The biology of desmids. Botanical Monographs 16. Oxford, Blackwell Scientific.

Brook AJ. 1984. Comparative studies in a polyphyletic group, the Desmidicaeae - 30 years on. In: Irvine DEG, John DM. (eds.) Systematics of the Green Algae (Systematics Association Special). Vol. 27. London, Academic Press. p. 251-269.

Carvalho JK, Burack C, Moresco C. 2015. Cosmarium (Zygnemaphyceae) de um lago do parque municipal Joaquim Teodoro de Oliveira, Campo Mourão-PR. SaBios-Revista de Saúde e Biologia 10: 1-13.

Cattaneo A, Galanti G, Gentinetta S, Romo S. 1998. Epiphytic algae and macroinvertebrates on submerged and floating-leaved macrophytes in an Italian lake. Freshwater Biology 39: 725-740.

Cavati B, Fernandes VO. 2008. Algas perifíticas em dois ambientes do baixo rio Doce (lagoa Juparanã e rio Pequeno - Juparanã e rio Pequeno - Linhares, Estado do Espírito Santo, Brasil): variação espacial e temporal. Acta Scientiarum Biological Sciences 30: 439-448.
Coesel PFM, Meesters J. 2007. Desmids of the Lowlands. Zeist nad Netherlands, KNNV Publishing.

Coesel PFM, Wardenaar K. 1990. Growth responses of planktonic desmid species in a temperature-light gradient. Freshwater Biology 23: 551560.

Coesel PFM. 1992. Desmid assemblies along altitude gradients in Colombia. Nova Hedwigia 55: 353-366.

Coesel PFM. 1996. Biogeography of desmids. Hydrobiologia 336: 41-53. Costa FM, Ramos GJP, Oliveira IB, Bicudo CEM, Moura CWN. 2018. Five new taxa and a new record of Euastrum (Desmidiaceae) from the Chapada Diamantina region, Bahia State, Brazil. Phytotaxa 372: 193-202.

Costa FM, Ramos GJP, Oliveira IB, Bicudo CEM, Moura CWN. 2020. Notes on the genus Euastrum (Desmidiaceae) in Brazil, with description of a new species. Phytotaxa 372: 193-202.

Couté A, Tell G. 1981. Ultrastructure de la paroi cellulaire des Desmidiacées au microscope électronique à la balayage. Beihefte zur Nova Hedwigia 68: 1-228.

Croasdale HT. 1956. Freshwater algae of Alaska I. Some desmids from the Interior. Part 2: Actinotaenium, Micrasterias and Cosmarium. Transactions of the American Microscopical Society 75: 1-70.

De-Lamonica-Freire EM, Heckman CW. 1996. The seasonal succession of biotic communities in wetlands of the tropical wet-and-dry Climatic Zone: III. The algal communities in the Pantanal of Mato Grosso, Brazil, with a comprehensive list of the known species and revision of two desmid taxa. Internationale Revue der gesamten Hydrobiologie 81: $253-280$

Delazari-Barroso A, Sant'anna CL, Senna PAC. 2007. Phytoplankton from Duas Bocas Reservoir, Espírito Santo State, Brazil (except diatoms). Hoehnea 34: 211-229.

Domitrovic YZ, Neiff JJ, Vallejos SV. 2013. Factores que regulan la distribution y abundancia del perifíton em ambientes lenticos. In: Schwarzbold A, Burliga AL, Torgan L.C. (eds.) Ecologia do perifíton. São Carlos, Rima Editora. p. 103-130.

Ehrenberg CG. 1843. Verbreitung und Einfluß des mikroskopischen Lebens in Süd- und Nord-Amerika. Berlin, Königlichen Akademie der Wissenschaften.

Felisberto SA, Rodrigues L. 2010. Cosmarium (Desmidiaceae, Zygnemaphyceae) da ficoflórula perifítica do reservatório de Rosana, bacia do rio Paranapanema, Paraná/São Paulo, Brasil. Hoehnea 37: 267-292.

Förster K. 1963. Desmidiaceen aus Brasilien. I. Nord-Brasilien. Revue Algologique, Nouvelle Série 7: 38-92.

Förster K. 1964. Desmidiaceen aus Brasilien, 2: Bahia, Goyaz, Piauhy und Nord- Brasilien. Hydrobiologia 23: 321-505.

França F, Melo E, Oliveira IB, Reis ATCC, Alves GL, Costa MF. 2010. Plantas vasculares das áreas alagadas dos Marimbus, Chapada Diamantina, Bahia, Brasil. Hoehnea 37: 719-730.

Freitas LC, Loverde-Oliveira SM. 2013. Checklist of green algae (Chlorophyta) for the state of Mato Grosso, Central Brazil. Check List 9: 1471-1483.

Fritsch FE, Rich MF. 1937. Contributions to our knowledge of the freshwater algae of Africa. 13. Algae from the Belfast Pan, Transvaal. Transactions of the Royal Society of South Africa 25: 153-228.

Gerrath JF. 1993. The biology of desmids: a decade of progress. In: Round FE, Chapman DJ. (eds.) Progress in phycological research. Vol. 9. Bristol, Biopress Ltd.. p. 79-192.

Gontcharov AA, Melkonian M. 2011. A Study of conflict between molecular phylogeny and taxonomy in the Desmidiaceae (Streptophyta, Viridiplantae): Analyses of 291 rbcL Sequences. Protist 162: 253-267.

Grönblad R, Croasdale HT. 1971. Desmids from Namibia (SW Africa). Acta Botanica Fennica 93: 1-40.

Grönblad R. 1921. New desmids from Finland and Northern Russia with critical remarks on some known species. Acta Societatis pro Fauna et Flora Fennica 49: 1-78.

Grönblad R. 1945. De algis brasiliensibus. Praecipue desmidiaceis in regione inferiore fluminis Amazonas a professore August Ginzberger (Wien). Anno MCMXXVII collectis. Acta Societatis Scienctiarum Fennicae, Nova Series B 2: 1-44. 
Guiry MD, Guiry GM. 2020. AlgaeBase. World-wide electronic publication, National University of Ireland, Galway. http: //www.algaebase.org. 11 Apr. 2020.

Hall JD, McCourt RM. 2017. Zygnematophyta. In: Archibald J, Simpson A, Slamovits C. (eds.) Handbook of the Protists. Cham, Springer. p. 135-163.

INMET. 2020. Instituto Nacional de Meteorologia. https: //portal.inmet. gov.br/dadoshistoricos. $10 \mathrm{Jul} .2020$.

Jung HC, Lee NJ, Kim DH, Lee OK. 2017. Four newly recorded taxa of charophytes and chlorophytes (Charophyta and Chlorophyta, Viridiplantae) in Korea. Korean Journal of Environmental Biology 35: 289-95.

Kanetsuna Y, Yamagishi T. 2018. Desmids of southeast Asia. Dera Dun, Bishen Singh Mahendra Pal Singh.

Kouwets FAC. 2001. Contributions to the knowledge of the French desmid flora 3. New and rare taxa from the regions of Dordogne and Limousin. Archiv für Hydrobiologie - Supplement 137: 27-55

Krieger W, Gerloff J. 1962 Die Gattung Cosmarium, Lieferung 1. Weinheim, Verlag von J. Cramer.

Krieger W, Gerloff J. 1965. Die Gattung Cosmarium. Liefrung 2. Weinheim, Verlag von J. Cramer.

Krieger W, Gerloff J. 1969. Die Gattung Cosmarium. Liefrung 3+4. Weinheim, Verlag von J. Cramer.

Krieger W. 1932. Die Desmidiaceen der Deutschen limnologischen SundaExpedition. Archiv für Hydrobiologie - Supplement 11: 129-230.

Krieger W. 1944. Süßwasseralgen aus Griechenland. Berichte der Deutsche Botanischen Gesellschaft 61: 250-270.

Krieger W. 1950. Desinidiaceen aus der montanen Region Südost-Brasiliens. Berichte der Deutschen Botanischen Gesellschaft 63: 36-43.

Leal IR, Tabarelli M, Silva JMC. 2003. Ecologia e conservação da Caatinga. Recife, Editora da Universidade Federal de Pernambuco.

Legendre P, Gallagher ED. 2001. Ecologically meaningful transformations for ordination of species data. Oecologia 129: 271-280.

Lemmermann E. 1914. Algologische Beiträge XIII. Über das Vorkommen von Algen in den Schläuchen von Utricularia. Abhandlungen Ferausgegeben vom Naturwissenschaftlichen Verein zu Bremen 23: 261-267.

Lima CT, Giulietti AM, Santos FA. 2012. Flora da Bahia: Nymphaeaceae. Sitientibus. Série Ciências Biológicas 12: 69-82.

Lundell PM. 1871. De Desmidiaceis, quae in Suecia inventae sunt, observationes criticae. Nova Acta Regiae Societatis Scientiarum Upsaliensis 8: 1-100.

McAbendroth L, Ramsay PM, Foggo A, Rundle SD, Bilton DT. 2005. Does macrophyte fractal complexity drive invertebrate diversity, biomass and body size distributions? Oikos 111: 279-290.

Menezes VC, Bueno NC, Sobjak TM, Bortolini JC, Temponi LG. 2013. Zygnemaphyceae associada à Utricularia foliosa L. no Parque Nacional do Iguaçu, Paraná, Brasil. Iheringia Série Botânica 68: 5-26.

Moro MF, Lughadha EN, Araújo FS, Martins FR. 2016. A phytogeographical metaanalysis of the semiarid Caatinga Domain in Brazil. The Botanical Review 82: 91-148.

Moura FBP, Marques JGW. 2007. The knowledge of traditional fisherman regarding the spatio-temporal dynamics of natural resources in the Chapada diamantina region, state of Bahia. Biota Neotropica 7: 119-126.

Nordstedt CFO. 1870. 18. Fam. Desmidiaceae. In: Warming E. (ed.) Symbolae ad floram Brasiliae centralis cognoscendam V. Videnskabelige Meddelelser fra den naturhistoriske Ferening i Kjöbenhavn for Aaret 1870-1879. Selskabets Bestyrelse, Kjöbenhavn. p. 195-234.

Nordstedt CFO. 1878. Nonnullae algae aquae dulcis brasilieses. Öfversigt af Kongl. Vetenskaps-Akademiens Forhandlingar 1877: 15-28.

Oksanen J, Blanchet FG, Kindt R, et al. 2011. Vegan: Community Ecology Package. R package version 1.17-6. http: //CRAN.R-project.org/ package=vegan. $10 \mathrm{Jul} .2020$.

Oliveira IB, Bicudo CEM, Moura CWN. 2010. Contribuição ao conhecimento de Cosmarium Corda ex Ralfs (Desmidiaceae, Zygnematophyceae) para a Bahia e o Brasil. Hoehnea 37: 571-600.

Oliveira IB, Bicudo CEM, Moura CWN. 2011. New records of Cosmarium (Desmidiaceae) to Brazil. Phytotaxa 26: 25-38.

OpenStreetMap. 2020 Planet dump. https: //www.openstreetmap.org/ 10 Aug. 2020.
Petlovany OA, Tsarenko PM. 2015. Desmidiales. In: Tsarenko PM, Wasser SP, Nevo E. (eds.) Algae of Ukraine: diversity, nomenclature, taxonomy, ecology and geography. Charophyta Vol. 4. Ruggell, Koeltz Scientific Books. p. 61-448.

Prescott GW, Croasdale HT, Vinyard WC, Bicudo CEM. 1981. A synopsis of North American desmids. Part II. Desmidiaceae: Placodermae Section 3. Lincoln, London, University of Nebraska Press.

Prescott GW, Scott, AM. 1942. The freshwater algae of Southern United States. I. Desmids from Mississippi, with descriptions of new Species and varieties. Transactions of the American Microscopical Society 61: 1-29.

Prescott GW. 1957. The Machris Brazilian expedition, Botany: Chlorophyta, Euglenophyta. Contributions in Science, Los Angeles County Museum 11: 1-29.

R Development Core Team. 2020. R: A language and environment for statistical computing. The R Foundation. https: //www.rproject.org. $10 \mathrm{Jul} 2020$.

Raciborski M. 1889. Nowe Desmidyje. Pamietnik Akademii Umiejetnosci w Krakowie. Wydzial Matematyczno 17: 73-113.

Ramos GJP, Bicudo CEM, Moura CWN. 2015. Oocystis apicurvata sp. nov. (Oocystaceae, Trebouxiophyceae), a new species of green algae from Chapada Diamantina, northeast Brazil. Brazilian Journal of Botany 38: 171-173.

Ramos GJP, Bicudo CEM, Moura CWN. 2017. Cosmarium bahianum, sp. nov. (Desmidiaceae), a new desmid species from a phytotelm habitat in the Brazilian restinga. Phytotaxa 291: 66-72.

Ramos GJP, Bicudo CEM, Moura CWN. 2018. Some new, rare and interesting desmids from bromeliad phytotelmata in Brazil. Phytotaxa 346: 59-77.

Ramos GJP, Costa FM, Santos MA, Moura CWN. 2019. Taxonomic novelties, new records, and rare species of desmids from the Chapada Diamantina region, Brazil. Phytotaxa 391: 185-196.

Ramos GJP, Santos MA, Oliveira IB, Moura CWN. 2020. Taxonomic and nomenclatural notes on five taxa of Cosmarium (Desmidiaceae, Zygnematophyceae) from Brazil. Notulae Algarum 146: 1-5.

Rosen BH, Stahlhut KN, Hall JD. 2019. Catalog of microscopic organisms of the Everglades, part 2 - The desmids of the Arthur R. Marshall Loxahatchee National Wildlife Refuge: U.S. Geological Survey Scientific Investigations Report 2019-5074. https://pubs.usgs.gov/ sir/2019/5074/sir20195074.pdf.

Roy J, Bisset JP. 1886. Notes on Japanese desmids. - No. I. Journal of Botany, London 24: 193-242.

Santos TR, Ferragut C, Bicudo CEM. 2013. Does macrophyte architecture influence periphyton? Relationships among Utricularia foliosa, periphyton assemblage structure and its nutrient $(C, N, P)$ status. Hydrobiologia 714: 71-83.

Schmidle W. 1893. Beiträge zur Algenflora des Schwartzwaldes und der Rheinebene. Bericht der Naturforschenden Gesellschaft zu Freiburg 7: 68-112.

Schmidle W. 1898. Über einige von Knut Bohlin in Pite Lappmark und Vesterbotten gesammelte Süsswasseralgen. Bihang till Kongliga Svenska Vetenskaps-Akademiens Handlingar 24: 1-71.

Scott AM, Grönblad R, Croasdale HT. 1965. Desmids from the Amazon Basin, Brazil, collected by Dr. H. Sioli. Acta Botanica Fennica 69: 3- 93.

Scott AM, Grönblad R. 1957. New and interesting desmids from the southeastern United States. Acta Societatis Scientarum Fennicae, Nova Series B 2: 3-62.

Silva AC, Souza AF. 2018. Aridity drives plant biogeographical sub regions in the Caatinga, the largest tropical dry forest and woodland block in South America. PLOS ONE 13: e0196130. doi: 10.1371/journal. pone. 0196130

Stamenkovic M, Hanelt D. 2017. Geographic distribution and ecophysiological adaptations of desmids (Zygnematophyceae, Streptophyta) in relation to PAR, UV radiation and temperature: a review. Hydrobiologia 787: 1-26.

Taylor WR. 1939. Fresh-water algae from the Petén District of Guatemala. Botaniska Notiser 1939: 112-124.

Thérézien Y. 1985. Contribution à l'étude des algues d'eau douce de la Guyane Française (à l'exclusion des Diatomées). Bibliotheca Phycologica 72: 5-275. 
Turland NJ, Wiersema JH, Barrie FR, et al. 2018. International Code of Nomenclature for algae, fungi, and plants (Shenzhen Code) adopted by the Nineteenth International Botanical Congress Shenzhen, China, July 2017. Regnum Vegetabile, Vol. 159. Glashütten, Koeltz Botanical Books. Turner WB. 1893. Algae aquae dulcis Indiae orientalis. The freshwater algae (principally Desmidieae) of East India. Kungliga Svenska VetenskapsAkademiens Handlingar 25: 1-187.

Uehlinger V. 1964. Ėtude statistique des methods de dénobrement planctoniqe. Archives des Sciences 17: 121-123.

West GS. 1909. The algae of the Yan Yean Reservoir, Victoria: a biological and ecological study. Journal of the Linnean Society, Botany 39: 1-88.
West GS. 1914. A contribution to our knowledge of the freshwater algae of Columbia. Mémoires de la Société des Sciences Naturelles de Neuchâtel 5: 1013-1051.

West W, West GS. 1896. Algae from Central Africa. Journal of Botany, British and Foreign 34: 377-384.

West W, West GS. 1898. On some desmids of the United States. Journal of the Linnean Society of London, Botany 33: 279-322.

West W, West GS. 1908. A monograph of the British Desmidiaceae. III. London, The Ray Society.

West W. 1892. A contribution to the freshwater algae of west Ireland. Journal of the Linnean Society of London, Botany 29: 103-216. 